Cite as: C. Garrido et al., Sci. Immunol. 10.1126/sciimmunol.abj3684 (2021).

\title{
SARS-CoV-2 vaccines elicit durable immune responses in infant rhesus macaques
}

\author{
Carolina Garrido' ${ }^{1}$, Alan D. Curtis $\mathrm{II}^{2}+$, Maria Dennis ${ }^{1}$, Sachi H. Pathak ${ }^{2}$, Hongmei Gao', David Montefiori', \\ Mark Tomai ${ }^{3}$, Christopher B. Fox ${ }^{4}$, Pamela A. Kozlowski ${ }^{5}$, Trevor Scobey ${ }^{6}$, Jennifer E. Munt ${ }^{6}$, Michael L. \\ Mallory $^{6}$, Pooja T. Saha ${ }^{7}$, Michael G. Hudgens ${ }^{7}$, Lisa C. Lindesmith ${ }^{6}$, Ralph S. Baric ${ }^{6}$, Olubukola M. Abiona ${ }^{8}$, \\ Barney Graham $^{8}$, Kizzmekia S. Corbett ${ }^{8}$, Darin Edwards ${ }^{9}$, Andrea Carfi ${ }^{9}$, Genevieve Fouda ${ }^{1}$, Koen K. A. Van \\ Rompay $^{10}$, Kristina De Paris ${ }^{2}{ }^{*}$, and Sallie R. Permar ${ }^{11}+$
}

\begin{abstract}
${ }^{1}$ Duke University Medical Center, Duke Human Vaccine Institute, Durham, NC, USA. ${ }^{2}$ Department of Microbiology and Immunology, Center for AIDS Research, and Children's Research Institute, School of Medicine, University of North Carolina at Chapel Hill, Chapel Hill, NC, USA. ${ }^{33}$ M Corporate Research Materials Laboratory, Saint Paul, MN, USA. ${ }^{4}$ Infectious Disease Research Institute, Seattle, WA, USA. ${ }^{5}$ Department of Microbiology, Immunology and Parasitology, Louisiana State University Health Sciences Center, New Orleans, LA, USA. ${ }^{6}$ Department of Epidemiology, Gillings School of Global Public Health, University of North Carolina at Chapel Hill, Chapel Hill, NC, USA. . Department of Biostatistics, Gillings School of Global Public Health, University of North Carolina at Chapel Hill, Chapel Hill, NC, USA. ${ }^{8}$ Vaccine Research Center, National Institute of Allergy and Infectious Diseases, National Institutes of Health, Bethesda, MA, USA. ${ }^{9}$ Moderna, Inc., Cambridge, MA, USA. ${ }^{10}$ California National Primate Research Center, University of California, Davis, CA, USA. ${ }^{11}$ Cornell Weill Medical College, New York, NY, USA.

† equal first authors

$\ddagger$ equal senior authors

*Corresponding author. Email: abelk@med.unc.edu
\end{abstract}

The inclusion of infants in the SARS-CoV-2 vaccine roll-out is important to prevent severe complications of pediatric SARS-CoV-2 infections and to limit transmission and could possibly be implemented via the global pediatric vaccine schedule. However, age-dependent differences in immune function require careful evaluation of novel vaccines in the pediatric population. Toward this goal, we assessed the safety and immunogenicity of two SARS-CoV-2 vaccines. Two groups of 8 infant rhesus macaques (RMs) were immunized intramuscularly at weeks 0 and 4 with stabilized prefusion SARS-CoV-2 S-2P spike (S) protein encoded by mRNA encapsulated in lipid nanoparticles (mRNA-LNP) or the purified S protein mixed with 3M052, a synthetic TLR7/8 agonist in a squalene emulsion (Protein+3M-052-SE). Neither vaccine induced adverse effects. Both vaccines elicited high magnitude IgG binding to RBD, N terminus domain, S1, and S2, ACE2 blocking activity, and high neutralizing antibody titers, all peaking at week 6 . S-specific memory B cells were detected by week 4 and S-specific T cell responses were dominated by the production of IL-17, IFN- $\gamma$, or TNF- $\alpha$. Antibody and cellular responses were stable through week 22 . The immune responses for the mRNA-LNP vaccine were of a similar magnitude to those elicited by the Moderna mRNA-1273 vaccine in adults. The S-2P mRNA-LNP and Protein-3M-052-SE vaccines were well-tolerated and highly immunogenic in infant RMs, providing proof-of concept for a pediatric SARS-CoV-2 vaccine with the potential for durable immunity that might decrease the transmission of SARS-CoV-2 and mitigate the ongoing health and socioeconomic impacts of COVID-19.

\section{INTRODUCTION}

Severe acute respiratory syndrome coronavirus 2 (SARSCoV-2) has infected hundreds of millions of people worldwide and caused over 3.5 million deaths since its emergence in 2019. The need for safe and effective measures to limit transmission and mitigate public health and socioeconomic impacts of SARS-CoV-2 infection has prompted unprecedented vaccine development of promising candidates. In fact two messenger RNA (mRNA) vaccines, mRNA-1273 (Moderna) (1, 2) and BNT162b2 (Pfizer-BioNTech) (3, 4), are authorized for emergency use in the United States to prevent SARS-CoV-2 infection in adults. Both are safe, and induce neutralizing antibodies and up to $95 \%$ protection from disease. Additionally, the Oxford/AstraZeneca adenovirus-based ChAdOx1 nCoV-19 (AZD1222) (5), the Johnson \& Johnson Ad26.COV2.S vaccine (JNJ-78436735) (6), and the first protein-based SARS-CoV-2 vaccine, Novavax NVX-CoV2373, adjuvanted with saponinbased Matrix-M $(7,8)$, are approved for use in human adults.

Ethical and safety risks warrant a careful evaluation of novel vaccines in the pediatric population. Generally, vaccine 
testing is performed in an age de-escalation manner, starting with adults, followed by adolescents, with children and infants being last (9). The BNT162b2 mRNA vaccine is now approved for use in adolescents 12 years and older, with trials for children age 6 to 12 already underway (NCT04816643). The Moderna mRNA-1273 vaccine is close to approval for use in children 12 years and older. Importantly, Moderna and Pfizer both have initiated clinical trials that will include infant as young as 6 months (NCT04796896 and NCT04816643, respectively). The important epidemiologic impact of pediatric SARS-CoV-2 vaccination lies in limiting transmission and ease of implementation via the global pediatric vaccine schedule.

Early in the pandemic, vaccines to prevent SARS-CoV-2 infection in children were not a priority because of apparent low infection and disease rates. In most children, SARS-CoV2 infection causes only relatively mild disease. Nonetheless, some children develop severe symptoms, such as the multisystem inflammatory syndrome, requiring hospitalization and sometimes leading to death (10-14). Importantly, severe complications of SARS-CoV-2 infection disproportionally affect children of ethnic and racial minorities, amplifying health disparities in pediatric care in the United States (15, 16). While children may transmit less efficiently than adults, virus transmission by children, even when asymptomatic, is documented $(17,18)$. Therefore, children have the propensity to become a major viral reservoir if pediatric vaccination stalls. The latter potential is especially concerning because new SARS-CoV-2 variants with increased transmission rates are emerging and SARS-CoV-2 has become more likely to persist on the population level. Although data are scarce, increased pediatric infection rates that appeared to coincide with the emergence of new variants, have been reported (19, 20 ). There is ample precedence for the beneficial impact of pediatric vaccination.

Children have suffered from the SARS-CoV-2 pandemic in many additional ways. We will not know the exact burden of the loss of education due to closure of schools and virtual learning until years from now. School closure meant that many children were deprived of social interactions, a food source, and a safe place (21-23). There has been an epidemic rise in depression and anxiety in children, and the long-term mental health burden of these diverse factors is difficult to assess. School closure also translated to loss of work for many parents, especially women. A pediatric SARS-CoV-2 vaccine could mitigate at least some of these societal costs.

These combined data emphasize the importance of getting children vaccinated for SARS-CoV-2 (24-27). However, vaccine-elicited immunity differs between adults and infants (reviewed in (28)), with impaired responses to carbohydrate antigen vaccines (29), but higher magnitude humoral immunity to subunit-based vaccines (e.g., Hepatitis B) (30) early in life. Thus, the evaluation of SARS-CoV-2 vaccine immunogenicity in infants is critical. Toward this goal, the present study was designed to evaluate the safety and immunogenicity of stabilized prefusion SARS-CoV-2 Spike vaccines delivered as lipid nanoparticle-encapsulated mRNA or an adjuvanted subunit protein in a relevant animal model. Nonhuman primates (NHP), including rhesus macaques (RMs), are an important model for SARS-CoV-2 studies given the similarities to humans in pathogenesis and host immune responses (31). Indeed, results from adult NHP studies of human SARS-CoV-2 vaccine candidates (32-35) strongly correlate with clinical trial outcomes, and infant NHP models of other infectious diseases closely mirror responses in human infants $(36,37)$. Data by our group support that infant vaccine-elicited antibody against HIV envelope can be of higher magnitude than those elicited by adults, (38) We also demonstrated that infant RMs generate high magnitude antibody responses to HIV Env protein vaccination, (39) and that peripheral and mucosal B cell responses can be boosted later in life. (40)

The primary goal of the current study was to inform human pediatric trials and aid in fast-tracking pediatric SARSCoV-2 vaccines for inclusion in the early life vaccine schedule by providing proof-of-concept that the two SARS-CoV-2 vaccines are safe and immunogenic in infant RMs. A secondary goal of our study was to assess the durability of vaccine-induced immune responses as data are lacking on this. Despite some caveats inherent to comparisons between studies with differences in study design, the immune responses in infant RMs in response to the two SARS-CoV-2 vaccines tested appear to be within the range of vaccine-induced immune responses reported for adult RMs $(32,41)$ and humans $(2,42$, 43).

\section{RESULTS}

\section{Study design and vaccine safety}

Infant RMs at a median age of 2.2 months, corresponding to 9-month old human infants (44), were immunized at weeks 0 and 4 with $30 \mu \mathrm{g}$ mRNA encoding stabilized prefusion SARS-CoV-2 S-2P protein in lipid nanoparticles (mRNA-LNP; $\mathrm{n}=8$ ) or with $15 \mu \mathrm{g}$ S-2P mixed with 3M-052-SE, a TLR7/8 agonist in a stable emulsion (Protein+3M-052-SE; $\mathrm{n}=8$ ) (Fig. 1, Table 1). Blood and saliva were collected before vaccination (week 0 ), 4 weeks after the first dose of the vaccine (week 4), 2 weeks after the vaccine boost (week 6), and at weeks 8, 14, 18 and 22. Lymph nodes were sampled at week 6 (Fig. 1).

Animals were monitored daily for adverse events. No local injection site or systemic adverse reactions were observed. Animals had normal blood metrics (Supplementary Table S1). Importantly, the animals gained weight consistent with adequate fluid and nutrition uptake and with normal infant 
growth (Supplementary Fig. S1) (45). A major safety concern in the implementation of a pediatric SARS-CoV-2 vaccine stems from adverse events observed with an earlier Respiratory Syncytial Virus vaccine, that were partially attributed to $\mathrm{T}$ helper $2\left(\mathrm{~T}_{\mathrm{H}} 2\right)$-biased responses $(46,47)$. We therefore tested plasma samples prior to or following immunization for changes in $\mathrm{T}_{\mathrm{H}} 2$ (IL-4, IL-13) or $\mathrm{T}_{\mathrm{H}} 1$ (IL-2, IFN- $\curlyvee$ ) cytokines (Fig. S2). Animal RM3 of the protein group (Table 1) tested positive for all cytokines at both time points; cytokines were also detected in the mRNA-LNP recipient RM11 at week 0 , but fell below the limit of quantification by week 6 . In general, neither vaccine appeared to induce systemic $\mathrm{T}_{\mathrm{H}} 2$ or $\mathrm{T}_{\mathrm{H}} 1$ responses (Fig. S2), further supporting a good safety profile.

\section{Infant plasma and salivary antibody responses to SARS- CoV-2 vaccination}

Plasma IgG binding to the S-2P protein was observed after the vaccine prime for both mRNA-LNP and Protein+3M-052SE vaccines and increased after the second immunization (Fig. 2). Although antibody levels dropped by week 8, there was only a slight decline of S-2P-specific IgG from week 8 to week 22 for mRNA-LNP (median AUC and 95\% confidence intervals: $7.0[6.2,8.3]$ to $5.4[4.2,7.7])$ or Protein+3M-052-SE (11.0 [9.5, 11.7] to 9.4 [8.6, 10.5] vaccinees (Fig. 2A). Longitudinal S-specific plasma IgG data reported as $\mathrm{EC}_{50}$ or endpoint dilution titers followed a similar trend (Fig. S3). As the D614G virus variant had become dominant in the USA at the study initiation, we confirmed that IgG binding to S-2P D614G was similar to that of D614 at weeks 6 and 14 (Fig. S4). Plasma IgG antibodies were directed against multiple spike domains and persisted throughout the study, with robust binding to Spike regions 1 and 2 (S1, S2), Receptor binding domain (RBD), and N-terminal domain (NTD) (Fig. 2B). RBD-specific salivary IgG from mRNA-LNP recipients peaked at a median of $16.6 \mathrm{ng}$ RBD-specific IgG per $\mu \mathrm{g}$ of total IgG at week 6 (Fig. $2 \mathrm{C})$. In the Protein+3M-052-SE group, median salivary RBDspecific IgG peaked at $98.2 \mathrm{ng} / \mu \mathrm{g}$ IgG after the second vaccination and remained detectable throughout the study (Fig. 2C). Saliva RBD-specific IgA responses were much lower (Fig. S5). Spike-specific IgM and IgA in plasma were low or undetectable (Fig. S5). In the mRNA-LNP group, IgM increased through week 14, but the absorbance readings for IgM were considered low, measured at a 1:10 sample dilution (Fig. S5).

\section{Function of vaccine-induced plasma antibodies}

We next evaluated the capacity of plasma antibodies to block entry of SARS-CoV-2 into human cells using a RBDACE2 blocking assay at 1:10 and 1:40 plasma dilutions. Antibodies elicited by the mRNA-LNP vaccine completely blocked RBD-ACE2 interaction at week 6 at 1:10 and 1:40 dilutions. Greater than $80 \%$ blocking was achieved at 1:10 dilution until week 14, dropping for some animals after week 18 (Fig. 3A). The Protein+3M-052-SE vaccine induced antibodies that mediated 100\% RBD-ACE2 blocking after the second immunization (Fig. 3A). At a 1:40 plasma dilution, the RBDACE2 blocking function decreased over time, but was still detectable at week 22 (Fig. S6).

Neutralizing antibodies, measured by a pseudovirus assay, were detected in all mRNA-LNP vaccinated animals and in 7 of 8 animals of the Protein+3M-052-SE group after the first vaccination, and further increased after the boost. Peak median infectious dose $80\left(\mathrm{ID}_{80}\right)$ titers were observed at week 6 and reached 1,179 in mRNA-LNP and 13,687 in Protein+3M052-SE animals (Fig. 3B). Similar to S-specific plasma IgG levels, and consistent with antibody kinetics after vaccination, median $\mathrm{ID}_{80}$ neutralization titers decreased following the peak response. Neutralization titers appeared to stabilize around week 18, and median $\mathrm{ID}_{80}$ titers at week 22 remained 2.6-fold or 14.2-fold higher in the mRNA-LNP or Protein+3M052-SE group, respectively, than after the first vaccination (week 4) (Fig. 3B). Although definite immune correlates of protection after vaccination still need to be conclusively determined, we modeled a bi-phasic antibody decline for both vaccines to reach a putative protective neutralizing Ab titer, estimated at a reciprocal dilution of 100 (41, 48). Applying this assumption, mRNA-LNP vaccinees maintained a protective neutralizing Ab titer for approximately 46 weeks and protein vaccine recipients for approximately 74 weeks (Fig. S7).

Neutralizing antibody kinetics in the whole virus neutralization assay followed a similar trend (Fig. 3C). The animal (RM 1) of the Protein+3M-052-SE group that did not have detectable neutralizing antibodies by week 4 in the pseudovirus neutralization assay, also only had a slight increase in the $\mathrm{ID}_{80}$ neutralizing antibody titer using the live virus assay (week 0: 129; week 4: 223). Overall, $\mathrm{ID}_{50}$ and $\mathrm{ID}_{80}$ titers of both assays strongly correlated with each other $(r=0.644$, $\mathrm{p}=0.008$ or $\mathrm{r}=0.785, \mathrm{p}=0.0005$, respectively Fig. S8). However, infant RMs already had low titer neutralizing antibodies at day 0 when we applied the whole virion neutralization assay (Fig. 3C). As infants could have passively acquired antibodies from their mothers, we measured neutralizing antibodies in the sera of their unvaccinated dams. Although detectable, neutralizing antibody titers in dams did not correlate to infant neutralization titers before $\left(\mathrm{ID}_{80}: \mathrm{r}=0.011, \mathrm{p}=0.96\right)$ or after vaccination $\left(\mathrm{ID}_{80}: \mathrm{r}=-0.056, \mathrm{p}=0.83\right.$ ) (Fig. S9), most likely because infant rhesus macaques were already 2 months old at study initiation and maternal antibodies had waned.

\section{Vaccine-elicited $B$ cell responses}

Consistent with the induction of plasma S-specific IgG, Sspecific memory $\mathrm{CD} 27^{+} \mathrm{B}$ cell were detectable in the blood of both vaccine groups at week 4 and peaked at week 6 (median: 0.75\% mRNA-LNP; 3.12\%, Protein+3M-052-SE). At week 14, median memory $\mathrm{B}$ cell frequencies were lower $(0.19 \%$ and $0.13 \%$ in mRNA-LNP or Protein+3M-052-SE vaccinees, respectively), but did not differ from those at week 4 (Fig. 4A). In lymph nodes (LNs), we measured total germinal center 
(GC) B cells and memory B cells and then determined the number of S-specific memory B cells (Fig. 4B). In both vaccine groups robust memory B cell populations (median $3.78 \%$ mRNA-LNP and $1.96 \%$ Protein-3M-052) were present (Fig. 4B). Induction of S-specific B cells was confirmed by assessing S-specific antibody secreting cells (ASC). In the blood, peak responses were observed at week 6 in the mRNA-LNP group (median: 154 ASC/million cells) and at week 8 in the Protein+3M-052-SE group (median: $85 \mathrm{ASC} / 10^{6}$ cells) (Fig. 4C). In draining LNs, mRNA-LNP and Protein+3M-052-SE vaccinees had median 6 or $952 \mathrm{ASC} / 10^{6}$ cells, respectively (Fig. 4D).

In addition, we analyzed LN samples for canonical $\mathrm{T}$ follicular helper $\left(\mathrm{T}_{\mathrm{FH}}\right)\left(\mathrm{CD} 185 / \mathrm{CXCR}^{+} \mathrm{CD} 279 / \mathrm{PD}^{+}{ }^{+}\right)$cells and for IL-4 or IL-21 producing CD4 ${ }^{+} \mathrm{T}$ cells that support GC B cell differentiation (Fig. 5A). SEB-activated $\mathrm{T}_{\mathrm{FH}}$ $\left(\mathrm{CD} 185^{+} \mathrm{CD} 279^{+} \mathrm{CD} 134^{+} \mathrm{CD} 137^{+}\right)$(49) (Fig. 5B) were categorized into $\mathrm{T}_{\mathrm{FH}} 1, \mathrm{~T}_{\mathrm{FH}} 2$ and $\mathrm{T}_{\mathrm{FH}} 17$ subsets based on expression of CXCR3/CD183 and/or CCR6/CD196 (50) (Fig. 5C). We found no correlations between bcl $6^{+} \mathrm{Ki} 67^{+} \mathrm{GC} \mathrm{B}$ cells or bcl6 $6^{+} \mathrm{T}_{\mathrm{FH}}$ (Fig. S10A, B), potentially because we assessed these cell populations in an antigen non-specific manner. However, $\mathrm{CD}^{+}{ }^{+} \mathrm{IL}_{21}{ }^{+}$cells correlated with pseudovirus neutralizing antibody $\mathrm{ID}_{50}$ at week $6(\mathrm{r}=0.749, \mathrm{p}=0.001)$ (Fig. S10C).

\section{Spike protein-specific $T$ cell responses}

In some animals, S-specific $\mathrm{CD} 4^{+} \mathrm{T}$ cell responses in PBMC were detected as early as week 4, with all animals producing at least a single cytokine by week 6 (Fig. 6; see Fig. S16 for gating strategies). At week $14, \mathrm{CD}^{+}{ }^{+} \mathrm{T}$ cells of mRNALNP vaccinated animals produced IL-2, IFN- $\gamma$, IL-17, and TNF- $\alpha$ responses (Fig. 6D), whereas IL-17 and IFN- $\gamma$ CD4 ${ }^{+} \mathrm{T}$ cell responses dominated in Protein+3M-052-SE vaccinees (Fig. 6D). Multifunctional CD4 ${ }^{+} \mathrm{T}$ cells co-produced IL-17 and IFN- $\curlyvee$ (Fig. S11), suggesting a $\mathrm{T}_{\mathrm{H}} 1 / \mathrm{T}_{\mathrm{H}} 17$ biased response. Although we did not measure IL-4 production, and limited cell numbers - typical for pediatric samples - prevented us from repeating the assay, it should be reiterated that neither of the vaccines caused a rise in systemic $\mathrm{T}_{\mathrm{H}} 2$ cytokines (Fig. S2). Sspecific peripheral blood $\mathrm{CD} 8^{+} \mathrm{T}$ cell responses appeared less robust than $\mathrm{CD}_{4}^{+} \mathrm{T}$ cell responses and only single-cytokine positive were elicited, but all animals produced at least a single cytokine in response to antigen stimulation (Fig. S12). In LNs, 6 of 8 and 8 of 8 animals in the mRNA-LNP or Protein+3M-052-SE group had S-specific $\mathrm{CD}^{+} \mathrm{T}$ cell responses, respectively. In addition, 8 of 8 mRNA-LNP vaccinees and 7 of 8 Protein+3M-052-SE vaccinees mounted S-specific CD8 ${ }^{+}$ $\mathrm{T}$ cell responses in LN at week 6 (Fig. S13).

Overall, these data suggested that infant RMs can mount robust antibody, including high titer neutralizing and ACE2 blocking antibodies, and T cell responses to SARS-CoV-2 vaccines. Vaccine-induced immune responses persisted for 22 weeks or 18 weeks after the first and second vaccine dose, respectively, results consistent with vaccine-induced memory.

\section{DISCUSSION}

Several SARS-CoV-2 vaccines have demonstrated safety, immunogenicity and protection in animal studies $(8,32,51$, 52 ) and in clinical trials with human adults $(1,5,6)$, and subsequently received authorization for emergency use in human adults. Considering the enormous health and socioeconomic impact of the SARS-CoV-2 pandemic on all age groups, clinical trials to test the safety of SARS-CoV-2 vaccines in adolescents and children have been initiated. In fact, the Pfizer-BioNTech mRNA vaccine is already approved for adolescents 12 years and older, Moderna's vaccine (NCT04796896) has recently been reported to be $96 \%$ effective in adolescents ages 12-17, and Novavax (NCT04611802) has an ongoing trial to test its vaccine this age group. However, data regarding the safety and immunogenicity of SARSCoV-2 vaccines in young infants are still lacking.

We reasoned that validating safety and immunogenicity of SARS-CoV-2 vaccines in infant rhesus macaques would provide beneficial information supporting the initiation of pediatric vaccine trials down to 6 months of age. Here, we present preclinical data demonstrating that infant rhesus macaques develop strong, durable humoral and cellular responses in the absence of adverse events following vaccination with a preclinical version of the Moderna mRNA-1273 vaccine or with stabilized prefusion S-2P SARS-CoV-2 protein mixed with 3M-052-SE, a TLR7/8 agonist in squalene emulsion. We selected the mRNA-LNP vaccine expressing S-2P because at the initiation of the study mRNA vaccines were quickly progressing through phase 3 clinical studies toward approval for human use, with EUA approval in the US in late 2020. We therefore considered this to be the class of vaccines most likely to be among the first vaccines to eventually progress for testing in the pediatric population. The 3M-052-SE adjuvant was chosen for the $\mathrm{S}-2 \mathrm{P}$ protein vaccine because this adjuvant has proven effective in eliciting high magnitude antibody responses to other vaccines in infant rhesus macaques $(39,53)$.

We assessed infant vaccine-induced immune responses over 22 weeks, analogous to adult clinical trials $(1,2)$. Both vaccines elicited plasma antibodies dominated by IgG and recognized all Spike protein domains. Binding antibodies persisted throughout the study in all animals of both groups. Interestingly, RBD-specific IgG was also detected in saliva, especially in animals of the protein vaccine group, and remained detectable throughout the study, similar to what has been observed after human natural infection (54). Moreover, 7 of 8 Protein $+3 \mathrm{M}-052$-SE vaccinated animals had RBDspecific IgA after the $2^{\text {nd }}$ immunization. The overall low induction of S-2P- and RBD-specific IgA by vaccination might be attributed to the delayed development of mucosal IgA 
compared to IgG responses in human and rhesus infants (5557). Vaccine-induced neutralizing antibody kinetics paralleled those observed for plasma binding antibodies and persisted for the duration of the study. At week 22, 18 weeks after the $2^{\text {nd }}$ dose, median ID $_{50}$ titers in the pseudovirus assay still exceeded $10^{3}$ for the protein vaccine group and $10^{2}$ for the mRNA group.

The immune correlates of protection against SARS-CoV-2 infection and disease still need to be conclusively determined $(58,59)$. To address this question, McMahan et al. (48) adoptively transferred plasma IgG from adult SARS-CoV-2 convalescent rhesus macaques and determined that a $\mathrm{S}$ proteinspecific reciprocal endpoint dilution ELISA titer of 400 and pseudovirus neutralizing antibody $\left(\mathrm{ID}_{50}\right)$ titers of approximately 50 can protect adult rhesus macaques against combined intratracheal and intranasal SARS-CoV-2 challenge (48). Applying these criteria to our results, we hypothesized that pediatric vaccination could provide protection against SARS-CoV-2 infection. However, we purposely decided to delay the challenge of our animals until one year post vaccination to better determine the long-term persistence of vaccineinduced neutralizing antibodies, which is especially important to a pediatric vaccine for a disease that affects all age groups. These data will be reported in a follow up study. Furthermore, the drop in ACE2-blocking function in some animals of the mRNA-LNP group raises the possibility that some of our vaccinated animals might develop disease, whereas others would be protected. Such an outcome would allow us to define immune correlates of protection, including the protective titer of neutralizing antibodies against infection and from severe disease, but also enable us to assess the contribution of other vaccine-induced immune responses (e.g., T cell responses) to protection.

Early life immunity is associated with $\mathrm{T}_{\mathrm{H}} 2$-biased $\mathrm{T}$ cell responses $(60)$, and $\mathrm{T}_{\mathrm{H}} 2$ responses have been linked to vaccine-associated enhanced respiratory disease in the context of protein or inactivated virus vaccines $(6,61,62)$. We observed a $T_{H} 1 / T_{H} 17$-skewed cytokine profile in circulating $\mathrm{S}$ specific $\mathrm{T}$ cells. Our finding of peak S-specific T cell responses 10 weeks post-boost are not unexpected. T cell reactivity in convalescent COVID-19 patients have augmented frequency and potency 100 days post-recovery, even as S-specific antibody waned (63). Indeed, $~ 93 \%$ of "exposed asymptomatic" patients possess SARS-CoV-2-specific memory T cell subsets in the absence of seroconversion (64). Higher $\mathrm{T}_{\mathrm{FH}} 2$ frequencies compared to $\mathrm{T}_{\mathrm{FH}} 1$ do not necessarily imply a $\mathrm{T}_{\mathrm{FH}} 2$-bias as $\mathrm{T}_{\mathrm{FH}} 17$ cells were also detected, and $\mathrm{T}_{\mathrm{FH}}$ were not assessed for antigen specificity. We found no evidence of systemic $\mathrm{T}_{\mathrm{H}} 2$ cytokines prior to or following immunization in either vaccine group, corroborating previous findings in adult macaques (32) and adult humans (42) that also demonstrated low level or absent $\mathrm{T}_{\mathrm{H}} 2$-mediated responses. IL-4 and IL-21 producing
$\mathrm{T}_{\mathrm{FH}}$ are required for the induction of GC B cells in LNs (65), indispensable for B cell and antibody affinity maturation, and GC reactions are important for positive outcomes in COVID19 patients (65). Indeed, the persistence of antibody was paralleled by sustained S-specific B cell responses. The induction and persistence of S-specific B cell clones described here may be key to protection against re-infection (66). In the current study, S-specific CD8 ${ }^{+} \mathrm{T}$ cell responses were lower compared to $\mathrm{CD}^{+} \mathrm{T}$ cell responses in the same animals. As $\mathrm{CD}^{+} \mathrm{T}$ cell response play an important role in the control of virus replication, future studies need to determine the contribution of vaccine-induced cytotoxic $\mathrm{T}$ cell responses to protection against SARS-CoV-2 infection.

Overall, the adjuvanted protein vaccine seemed to elicit stronger immune responses compared to the mRNA vaccine. We can only speculate why the vaccine-induced immune responses were different between the Protein+3M-052-SE and the mRNA-LNP regimens. First, we do not know the exact amount of protein expressed by the mRNA-LNP vaccine in vivo. Second, we and others have previously demonstrated that the TLR7-8-based adjuvant 3M-052 is highly effective in enhancing antibody responses in the rhesus macaque model $(39,53)$. TLR7/8 agonists, in contrast to most other TLR agonists, promote potent IL-12 responses by antigen-presenting cells (67-69) that in neonates and young infants are normally biased toward IL-23 production (70). Therefore, the priming of $\mathrm{T}$ helper cells and antibody responses is assumed to be improved by the inclusion of the 3M-052-SE adjuvant. Nonetheless, the data do not imply that the mRNA-LNP vaccine was less successful in inducing immune responses compared to responses observed in human clinical trials or in adult NHP. In fact, S-specific T and B cell responses to the mRNA-LNP vaccine persisted throughout the study period.

It is difficult to directly compare the results of the current study with published data from human clinical trials or from adult NHP studies. We are not aware of published data using the Protein+3M-052-SE vaccine for SARS-CoV-2 in NHP. Results from human and NHP studies with the mRNA-1273 vaccine are listed in Table $2(2,32,41-43)$. It should be noted that the various studies differed in their design. Keeping this caveat in mind, the magnitude, quality, and durability of the mRNA-LNP vaccine-induced responses in infant macaques appear to be within the range of those observed in adult NHP and human studies.

We demonstrated that infant rhesus macaques mount strong and durable responses to mRNA-LNP and proteinbased SARS-CoV-2 vaccines that were comparable to adults without adverse reactions. These promising results endorse clinical translation of SARS-CoV-2 vaccines to early life populations. Even when the majority of adults and adolescents have been vaccinated and herd immunity is achieved, globally about 140 million infants are born each year (71) and they 
will be naïve and susceptible to SARS-CoV-2 once passively transferred maternal antibodies wane. Being cautiously optimistic, a multivalent SARS-CoV-2 vaccine effective against major circulating viral variants appears feasible and could become part of the standard pediatric vaccine program.

\section{MATERIALS and METHODS}

\section{Study Design}

The objective of this study was to provide proof-of-concept that young infants ( $<1$ year) could mount functional and durable neutralizing antibody responses and $\mathrm{T}$ cell responses to SARS-CoV-2 vaccination. Considering the extent of the SARSCoV-2 pandemic, the rapid emergence of new viral variants with increased transmission rates with yet unknown impact on pediatric infections, our goal was to inform human SARSCoV-2 vaccine age de-escalation studies to fast-track vaccine implementation in the pediatric population. Utilizing the highly relevant infant rhesus macaque model, we tested the safety and immunogenicity of a preclinical version of the mRNA 1273 SARS-CoV-2 vaccine $(n=8)$ and a stabilized prefusion SARS-CoV-2 S-2P spike (S) protein vaccine mixed with the 3M-052 adjuvant in stable emulsion $(n=8)$ (Fig. 1; Table 1). S-specific cellular responses and antibody responses were monitored for 22 weeks.

\section{Animals}

Infant male $(n=8)$ and female $(n=8)$ rhesus macaques (Macaca mulatta; RM) of Indian-origin from the California National Primate Research Center (CNPRC, Davis, CA) breeding colony (negative for type $\mathrm{D}$ retrovirus, simian immunodeficiency virus, simian lymphocyte tropic virus type 1 and SARS-CoV-2), were enrolled at a median age of 2.2 months and randomly assigned into two groups (Table 1). Infants were housed with their dams until about 6 months of age, and then weaned and pair-housed. Animal care was in compliance with the "Guide for Care and Use of Laboratory Animals" by the Institute for Laboratory Animal Research. Animal procedures were approved by the UC Davis Institutional Animal Care and Use Committee prior to study initiation. All procedures were performed under anesthesia (ketamine, $10 \mathrm{mg} / \mathrm{kg}$ body weight, intramuscularly [IM]). Blood, saliva and lymph nodes (LN) were collected and processed as described (72).

\section{Preparation of the SARS CoV2 Spike protein}

The CoV2 Spike (73) (2019-nCoV) protein was transiently expressed in Freestyle HEK293 cells (Thermo Scientific) by first diluting the plasmid in Opti-MEM-1 (Gibco) medium; $0.8 \mathrm{mg}$ of plasmid in $25 \mathrm{~mL}$ of Opti-MEM-1 for each liter of cells transfected and sterile filtered using a $0.22 \mu \mathrm{m}$ filter. 1 $\mathrm{mL}$ of 293 fectin (Gibco) was diluted in $25 \mathrm{~mL}$ of Opti-MEM-1 and allowed to incubate at room temperature for $5 \pm 1 \mathrm{~min}$. The plasmid and the 293fectin mixtures were combined and swirled to mix, then incubated at room temperature for $25 \pm$
5 min. During the incubation, the Freestyle HEK293 cells were diluted to $1.25 \times 106$ cells/ $\mathrm{mL}$ in a 2-liter Corning flask. At the end of the $25 \pm 5$ min incubation of the 293 fectin and plasmid mixtures, $50 \mathrm{~mL}$ of the transfection mixture was added to each flask of diluted cells with gentle agitation of the flask during addition. The cell + transfection mixture was then split between two 2-liter Corning flasks for a final volume of approximately $500 \mathrm{~mL}$ each and placed on a platform shaker in a humidified incubator at $37^{\circ} \mathrm{C}$ with $8 \% \mathrm{CO}_{2}$. The shaker speed was set to 120rpm and the flasks allowed to incubate for 6 days. At the end of the 6-day incubation, the flasks containing the transfected cells were removed from the incubator and the contents of the flasks were aseptically transferred to 500mL Corning centrifuge tubes. The supernatant was clarified by centrifugation and subsequently filtered using a $0.8 \mu \mathrm{m}$ filter bottle system. Keeping the clarified and filtered supernatant on ice, the supernatant was concentrated using a Sartorius Vivaflow 200 30kDa TFF system. In preparation for the purification of the CoV2 Spike protein, $4 \mathrm{~mL}$ of Strep-Tactin Resin (iba Life Science) was placed in a conical tube. The concentrated supernatant was transferred to the conical tube containing the Strep-Tactin resin and allowed to bind with gentle agitation. The supernatant and resin were then transferred to a polypropylene column for gravity-flow chromatography (BioRad). Once the resin had settled in the column the resin was washed and the protein eluted following instructions supplied by the vendor (iba Life Science). The eluate was buffer-exchanged into $2 \mathrm{mM}$ Tris and $200 \mathrm{mM}$ Sodium Chloride storage buffer using Millipore Centrifugal filters. The resulting material was finally filtered through a 0.2 um syringe filter (Pall) and stored in storage buffer. Additional purification by size exclusion chromatography over a Superose 6 column was performed to increase purity.

\section{Vaccines}

The SARS-CoV-2 stabilized prefusion Spike (S-2P) mRNALNP vaccine was provided by Moderna, Inc. and the Vaccine Research Center (NIH) provided the S-2P protein. The vaccine regimen and specimen collection are outlined in Fig. 1. In humans, the dose of the Moderna mRNA-1273 vaccine is $100 \mu \mathrm{g}$. However, even a $25 \mu \mathrm{g}$ dose has proven immunogenic and was associated with fewer side effects compared to the $100 \mu \mathrm{g}$ in older adults (42). In adult RMs, a $10 \mu \mathrm{g}$ dose regimen induced significantly lower neutralizing antibody responses than the $100 \mu \mathrm{g}$ vaccine (32). Thus, balancing immunogenicity and safety, we decided to immunize infant RMs in the mRNA-LNP vaccine group IM at weeks 0 (quadriceps) and 4 (biceps) with $30 \mu \mathrm{g}$ mRNA encoding S-P2 protein in lipid nanoparticles (mRNA-LNP), administered in 0.1 $\mathrm{mL}$ phosphate-buffered saline. Note that the vaccine was stored at $-80^{\circ} \mathrm{C}$ until just prior to the immunization. Infant RMs in the protein vaccine group were injected IM with15 $\mu \mathrm{g}$ S-2P protein mixed with 3M-052-SE, an adjuvant formulation 
consisting of $10 \mu \mathrm{g}$ of the synthetic TLR7/8 agonist 3M-052 in a $2 \% \mathrm{v} / \mathrm{v}$ squalene-in-water emulsion (Protein $+3 \mathrm{M}-052-\mathrm{SE}$ ) in $0.5 \mathrm{~mL}$ divided across the left and right quadriceps (week 0 ) or biceps (week 4).

\section{Plasma IgG ELISA}

IgG binding to the stabilized SARS-CoV-2 spike protein S$2 \mathrm{P}$ with or without the D614G mutation was measured in plasma using enzyme-linked immunosorbent assay (ELISA) as previously described (74). 384-well plates were coated overnight with $2 \mathrm{ug} / \mathrm{mL}$ of spike protein produced by the Protein Production Facility (PPF) at the Duke Human Vaccine Institute. Plates were then blocked with assay diluent (phosphate-buffered saline containing $4 \%$ whey, $15 \%$ normal goat serum, and $0.5 \%$ Tween 20 ). 10 serial 4 -fold dilutions of plasma starting at 1:40 were added to the plates and incubated for 1 hour, followed by detection with a horseradish peroxidase (HRP)-conjugated antibody mouse anti-monkey IgG (Southern Biotech). The plates were developed by using an ABTS-2 [2,2'-azinobis(3-ethylbenzthiazolinesulfonic acid)] peroxidase substrate system (KPL) and absorbance was read at $450 \mathrm{nM}$ with a Spectramax Microplate Reader (Molecular Devices). Results were calculated as area under the curve (AUC) and EC50 values. AUC values were calculated using the Trapezoidal rule. EC50 values were calculated by fitting a 4parameter logistic function using nonlinear regression. Pooled Non-Human Primate Convalescent Serum to SARSCoV-2 (BEI Resources NR-52401) was used in all assays to ensure inter-assay reproducibility, but standard curves were not developed given the lack of a rhesus macaque-specific IgG reagent of known concentration. IgM and IgA binding to S-2P was measured in a single 1:10 diluted plasma sample following the same ELISA protocol but using as detection antibody anti-Human IgM HRP (Jackson Immunoresearch) for IgM detection and 10F12-biotin (NHP Reagent Resource) with Streptavidin-HRP (Pierce) for IgA detection. Results are expressed as OD450.

\section{Measurement of Salivary S-specific IgG and IgA}

Saliva was collected with absorbent Merocel sponges (Beaver Visitec) by placing a sponge between the cheek and gum in the back of the mouth for $5 \mathrm{~min}$. Secretions were eluted by centrifugation at $18,000 \mathrm{~g}$ and $4^{\circ} \mathrm{C}$ after addition of $50 \mathrm{ul}$ of PBS containing protease inhibitors (75), 1\% TritonX$100,1 \%$ BSA, $0.05 \%$ azide, and $0.05 \%$ Tween- 20 to sponges. A customized binding antigen multiplex assay (BAMA) was used to measure IgG or IgA antibodies to SARS CoV-2 recombinant receptor binding domain protein (RBD; generously provided by Dr. Wrammert, Emory University, Atlanta, GA) and S2 extracellular domain (SinoBiologicals \#40590-V08B, Wayne, PA). Briefly, proteins were dialyzed in PBS and conjugated to Bioplex Pro carboxylated magnetic beads (Bio-Rad, Hercules, CA) using N-hydroxysulfosuccinimide and ethylcarbodiimide as described (76). Serial dilutions of standard and centrifuged salivary secretions in PBS containing $1 \%$ TritonX-100, $1 \%$ BSA, $0.05 \%$ azide, and $0.05 \%$ Tween- 20 were mixed with $\mathrm{RBD}+\mathrm{S} 2$ beads overnight at $1100 \mathrm{rpm}$ and $4^{\circ} \mathrm{C}$ using a plate mixer. The IgG standard was a cocktail of anti-S1 RBD (Genscript \#HC2001) and anti-S2 (SinoBiologicals \#40590-D001) humanized IgG monoclonal antibodies. The standard for IgA assays was a pooled serum from infected rhesus macaques (77) that had been calibrated relative to the previously mentioned monoclonal antibodies. The following day, beads were alternately washed using a Bio-Rad BioPlex wash station and treated for $30 \mathrm{~min}$ with $2 \mu \mathrm{g} / \mathrm{ml}$ biotinylated affinity-purified goat antibody to human $\gamma$ chain (SouthernBiotech Associates, Birmingham, AL) or clone IgA5-3B mouse anti-monkey IgA (Bio-Rad) followed by $1 / 400$ avidin-phycoerythrin (Southern Biotechnology Associates). A Bio-Rad Bioplex 200 and BioManager software were used to measure fluorescent intensity and construct standard curves for interpolation of antibody concentrations in test samples. Concentrations of antibody measured in a Luminex-based binding antibody multiplex assay (BAMA) were normalized relative to the total IgG and IgA measured by ELISA as described (75) using plates coated with goat anti-monkey IgG or IgA and the secondary antibodies above.

\section{Plasma S-specific IgG Epitope Mapping}

SARS-CoV-2 antigens, including whole spike (produced by PPF), S1 (Sinobiological cat\# 40591-V08H), S2 (Sinobiological cat\# 40590-V08B), RBD (Sinobiological cat\# 40592-V08H) and NTD (Sinobiological cat\# 40591-V49H) were conjugated to Magplex beads (Bio-Rad, Hercules, CA). The conjugated beads were incubated on filter plates (Millipore, Stafford, VA) for 30 min before plasma samples were added. Plasma samples were diluted in assay diluent ( $1 \%$ dry milk, $5 \%$ goat serum, and $0.05 \%$ Tween 20 in $1 \times$ phosphate buffered saline, $\mathrm{pH}$ 7.4.) at a 1:10,000-point dilution. Beads and diluted samples were incubated for 30 min with gentle rotation, and IgG binding was detected using a phycoerythrin (PE)-conjugated mouse anti-monkey IgG (Southern Biotech, Birmingham, Alabama) at $2 \mu \mathrm{g} / \mathrm{ml}$. Plates were washed and acquired on a BioPlex 200 instrument (Bio-Rad, Hercules, CA), and IgG binding was reported as mean fluorescence intensity (MFI). To assess assay background, the MFIs of wells without sample (blank wells) were used, as well as evaluated nonspecific binding of the samples to unconjugated blank beads.

\section{RBD-ACE2 Blocking Assay}

Corning 384-well plates were coated with $3.5 \mathrm{ug} / \mathrm{mL}$ ACE2 protein (Sinobiological) 24 hours before conducting the experiment. The day of the assay, the plate was blocked with assay diluent (phosphate-buffered saline containing 4\% whey, $15 \%$ normal goat serum, and $0.5 \%$ Tween 20 ) for 1 hour at room temperature. Plasma was diluted 1:10, 1:40, or 1:60 using the assay diluent, and incubated with $1 \mathrm{ug} / \mathrm{mL}$ HRPRBD protein (Genescript) at $37 \mathrm{C}$ for 1 hour. Plates were 
washed and the preincubated mixture of plasma and HRPRBD protein was added in duplicates and incubated at RT for 1 hour. Then, plates were washed 4 times to remove unbound sample, and peroxidase substrate solution (SeraCare) was added for $4 \mathrm{~min}$ before stopping the reaction using stop solution (SeraCare). Signal was detected using a Spectramax plate reader at OD 450. The amount of signal detected in wells without sample (diluent only) was considered the maximal binding response, and the OD450 detected in the sample wells was transformed to percentage inhibition compared to maximum binding. Data presented is the average of two replicates when $\mathrm{CV}$ is less than $20 \%$, and if different assays were performed, median value was considered.

\section{Pseudovirus Antibody Neutralization Assay}

SARS-CoV-2 neutralization was assessed with Spikepseudotyped viruses in 293T/ACE2 cells as a function of reductions in luciferase (Luc) reporter activity. 293T/ACE2 cells were kindly provided by Drs. Farzan and Mu at Scripps Florida. Cells were maintained in DMEM containing 10\% FBS, 25 $\mathrm{mM}$ HEPES, $50 \mu \mathrm{g} / \mathrm{ml}$ gentamycin and $3 \mu \mathrm{g} / \mathrm{ml}$ puromycin. An expression plasmid encoding codon-optimized full-length Spike of the Wuhan-1 strain (VRC7480), was provided by Drs. Graham and Corbett at the Vaccine Research Center, National Institutes of Health (USA). The D614G amino acid change was introduced into VRC7480 by site-directed mutagenesis using the QuikChange Lightning Site-Directed Mutagenesis Kit from Agilent Technologies (Catalog \# 210518). The mutation was confirmed by full-length Spike gene sequencing. Pseudovirions were produced in HEK 293T/17 cells (ATCC cat. no. CRL-11268) by transfection using Fugene 6 (Promega Cat\#E2692) and a combination of Spike plasmid, lentiviral backbone plasmid (pCMV $\triangle \mathrm{R} 8.2$ ) and firefly Luc reporter gene plasmid (pHR' CMV Luc) (78) in a 1:17:17 ratio. Transfections were allowed to proceed for 16-20 hours at $37 \mathrm{oC}$. Medium was removed, monolayers rinsed with growth medium, and $15 \mathrm{ml}$ of fresh growth medium added. Pseudovirus-containing culture medium was collected after an additional 2 days of incubation and was clarified of cells by lowspeed centrifugation and $0.45 \mu \mathrm{m}$ micron filtration and stored in aliquots at $-80^{\circ} \mathrm{C}$. $\mathrm{TCID}_{50}$ assays were performed on thawed aliquots to determine the infectious dose for neutralization assays.

For neutralization, a pre-titrated dose of pseudovirus was incubated with 8 serial 5 -fold dilutions of serum samples in duplicate in a total volume of $150 \mu \mathrm{l}$ for 1 hour at $37 \mathrm{oC}$ in $96-$ well flat-bottom poly-L-lysine-coated culture plates (Corning Biocoat). Cells were suspended using TrypLE Select Enzyme solution (Thermo Fisher Scientific) and immediately added to all wells $(10,000$ cells in $100 \mu \mathrm{L}$ of growth medium per well). One set of 8 control wells received cells + virus (virus control) and another set of 8 wells received cells only (background control). After 66-72 hours of incubation, medium was removed by gentle aspiration and $30 \mu \mathrm{L}$ of Promega 1X lysis buffer was added to all wells. After a 10-min incubation at room temperature, $100 \mu \mathrm{l}$ of Bright-Glo luciferase reagent was added to all wells. After 1-2 min, $110 \mu \mathrm{l}$ of the cell lysate was transferred to a black/white plate (Perkin-Elmer). Luminescence was measured using a PerkinElmer Life Sciences, Model Victor2 luminometer. Neutralization titers are the serum dilution at which relative luminescence units (RLU) were reduced by either $50 \%\left(\mathrm{ID}_{50}\right)$ or $80 \%\left(\mathrm{ID}_{80}\right)$ compared to virus control wells after subtraction of background RLUs. Serum samples were heat-inactivated for $30 \mathrm{~min}$ at $56 \mathrm{C}$ prior to assay.

\section{Whole Virus Neutralization Assay}

Neutralization of SARS-CoV-2 nanoLUC carrying the D614G mutation was assessed as described in Hou et al. with modifications (79). Briefly, under BSL-3 containment, serially diluted sera at 8 dilutions were incubated for one hour with SARS-CoV-2 D614G nanoLUC virus at $5 \% \mathrm{CO}_{2}$ and $37^{\circ} \mathrm{C}$. After incubation, the virus/antibody mixtures were added in duplicate to black 96-well plates containing Vero E6 cells (2x10 cells/well). Each plate contains virus-only (no serum) control wells. The plates were incubated for 24 hours at $37^{\circ} \mathrm{C}, 5 \% \mathrm{CO}_{2}$, the cells lysed, and luciferase activity measured with the Nano-Glo Luciferase Assay System (Promega). Neutralization activity is expressed as the dilution concentration at which the observed relative light units (RLU) are reduced by $50 \%$ or $80 \%$ relative to virus-only control wells.

\section{Preparation of S-specific Hook Reagents for Flow Cy- tometry}

To express the prefusion $\mathrm{S}$ ectodomain, a gene encoding residues 1-1208 of 2019-nCoV S (GenBank: MN908947) with proline substitutions at residues 986 and 987, a "GSAS" substitution at the furin cleavage site (residues 682-685), a Cterminal T4 fibritin trimerization motif, an HRV3C protease cleavage site, a TwinStrepTag and an 8XHisTag was synthesized and cloned into the mammalian expression vector $\mathrm{p} \alpha \mathrm{H}$. To express the 2019-nCoV RBD-SD1, residues 319-591 of 2019-nCoV S were cloned upstream of a C-terminal HRV3C protease cleavage site, a monomeric Fc tag and an 8XHisTag. Similarly, to express the SARS-CoV RBD-SD1, residues 306-577 of SARS-CoV S (Tor2 strain) were cloned upstream of a C-terminal HRV3C protease cleavage site, a monomeric $\mathrm{Fc}$ tag and an 8XHisTag. Dimers are prepared based on the molar ratio $(2: 1)$ of the analyte protein and fluorochromeconjugated Strep-Tactin, respectively. PE (IBA GmbH, 65000-001) or APC (IBA GmbH, 6-5010-001) conjugated StrepTactin was reacted with the protein over 5 additions, incubating for $15 \mathrm{~min}$ between each addition. The final concentration of tetramer was calculated with respect to the analyte protein. The solution was aliquoted based on the expected usage per experiment, snap frozen, and stored at $-80^{\circ} \mathrm{C}$. For quality control, monoclonal antibodies were bound to polystyrene 
beads (Spherotech) per the manufacturer's instructions. B cell hooks were tested on beads coated with Ab026204 and CH65; mAb Ab026204 binds SARS-CoV2, mAb CH65 binds influenza hemagglutinin (80) and was used a negative control. Briefly, $0.5 \mu \mathrm{L}$ of beads were diluted to $25 \mu \mathrm{L}$ in PBS $+0.02 \%$ NaN3. The bead mixture was added to 6 wells (25 $\mu \mathrm{L}$ per well) in a 96 -well filter plate. B cell hooks were diluted to a final concentration of $40 \mu \mathrm{g} / \mathrm{mL}$ in $175 \mu \mathrm{L}$ of PBS+0.02\% $\mathrm{NaN} 3$, then four serial 2-fold dilutions were made down to a final concentration of $5 \mu \mathrm{g} / \mathrm{mL}$. Test conjugate dilutions (25 $\mu \mathrm{L}$ per well) were added to each bead set, with one additional well of each bead set left as an unstained control. After 30min incubation, the solution was vacuumed off and the beads washed 3 times with $150 \mu \mathrm{L}$ PBS $+0.02 \%$ NaN3. The washed beads were resuspended in $125 \mu \mathrm{L}$ of $\mathrm{PBS}+0.02 \% \mathrm{NaN} 3$, and the samples were run on a BD LSRII cytometer within 4 hours of preparation. Data were analyzed using Flow Jo software (Treestar) and plots of each dilution compared to the unstained control.

\section{Antigen-specific B Cell Quantitation}

S-specific B cells were assessed by flow cytometry as described (39) (Table S1). Freshly isolated or archived (week 6) PBMC or LNC $\left(2 \times 10^{6}\right.$ cells) were washed with phosphate buffered saline (PBS, Gibco) and pelleted by centrifugation at 500 $\times \mathrm{g}$ for $7 \mathrm{~min}$. Cells were resuspended in $150 \mu \mathrm{L} 1 \%$ bovine serum albumin (BSA, Sigma-Aldrich) $+5 \mu \mathrm{M}$ Chk2 inhibitor II in PBS and incubated $15 \mathrm{~min}$ at $4 \mathrm{C}$ in the dark, and subsequently washed with PBS $+1 \%$ BSA $(7 \mathrm{~min}$ at $500 \times \mathrm{g})$. The cell pellet was stained with antibodies prescribed in Table S2 for $30 \mathrm{~min}$ in the dark at $4 \mathrm{C}$. Total $\mathrm{CD} 20^{+}$and/or memory $\mathrm{CD} 27^{+}$S-specific B cells were identified as double-positive for biotinylated S-2P protein labeled with avidin-APC or avidinPE (Fig. S14). Germinal center (GC) B cells were analyzed by flow cytometry (Table S2) as detailed elsewhere (81). After staining, cells were washed as before and fixed with $1 \%$ paraformaldehyde before immediate acquisition on an LSRFortessa (BD) using BD FACSDiva v.8.0 and analyzed with FlowJo software v10.7.1 (Fig. S15).

\section{B Cell ELISpot}

Polyvinylidene fluoride membranes (Millipore) were activated with $70 \%$ ethanol for $1 \mathrm{~min}$, subsequently coated with 1 $\mu \mathrm{g}$ SARS-CoV-2 Spike protein (2019-nCoV) per well and blocked for 2 hours with $2 \%$ milk and stored at $4 \mathrm{C}$. Fresh or thawed cell preparations were washed and stimulated $\left(10^{6}\right.$ cells/mL) with $1 \mu \mathrm{g} / \mathrm{mL}$ R848 (InvivoGen, San Diego, CA) and $10 \mathrm{ng} / \mathrm{mL}$ human IL-2 (Miltenyi Biotec) for 72 hours in complete medium (cRPMI): RPMI-1640 medium (Gibco) containing penicillin, streptomycin, L-glutamine (Sigma-Aldrich), and $10 \%$ heat-inactivated FBS (Gibco). Stimulated cells $(8 \times$ $10^{4} /$ well) were incubated in triplicate wells of SARS-CoV-2 Spike protein-coated microtiter plates overnight at $37^{\circ} \mathrm{C}$, washed with PBS+0.05\% Tween 20, and incubated 1 hour with $1 \mu \mathrm{g} / \mathrm{mL}$ biotinylated affinity-purified goat anti-human IgG (Southern Biotech) at room temperature. Plates were washed with PBS+0.05\% Tween 20, incubated with a 1:4000 dilution of avidin-peroxidase (Southern Biotech) for 1 hour at room temperature, and developed using the BD AEC kit using $100 \mu \mathrm{L}$ per well. Dried membranes were analyzed with an automated ELISpot Reader System (Autoimmun Diagnostika $\mathrm{GmbH}$ ). Results are reported as the number of antibody-secreting cells (ASC) per $10^{6}$ MNCs.

\section{T Cell Responses}

Cryopreserved cells were thawed, or fresh preparations were washed and cultured in cRPMI $\left(10^{6} / \mathrm{mL}\right)$ with or without $2 \mu \mathrm{g} / \mathrm{mL}$ overlapping peptides spanning the length of SARS-CoV-2 spike protein (JPT Technologies) or DMSO vehicle together with co-stimulatory antibodies against CD28 and CD49d from BD. Naïve donor cells were included with each assay and, in addition to peptide pool or vehicle, were stimulated with $0.5 \mathrm{x}$ cell stimulation cocktail (eBiosciences) as a positive control. Cells were surface stained as outlined in Table S2 and then permeabilized with BD CytoFix/CytoPerm per manufacturer's recommendations and stained with intracellular antibodies as prescribed in Table S2. Data were collected using an LSRFortessa and BD FACSDiva v8.0 and analyzed with FlowJo software v10.7.1 (TreeStar). Intracellular cytokine gates (Fig. S16) were Boolean gated and reported as single positive events unless otherwise noted.

In addition, we performed the activation-induced marker (AIM) assay $(49,82)$ on cryopreserved LNC. Cells were thawed, rested $3 \mathrm{~h}$ at $37^{\circ} \mathrm{C}$ with $5 \% \mathrm{CO} 2$, resuspended in AIM $\mathrm{V}$ medium (Gibco), and transferred at $10^{6}$ cells per well to a 24-well plate. Cells were cultured with vehicle DMSO (negative control) or with $0.5 \mu \mathrm{g} / \mathrm{ml}$ staphylococcal enterotoxin B (Toxin Technologies) for 20 hours at $37^{\circ} \mathrm{C}$ with $5 \% \mathrm{CO}_{2}$. After stimulation, cells were stained with prescribed antibodies per Table S2 and acquired immediately on an LSRFortessa instrument running FACSDiva v8.0 software (BD Biosciences) and analyzed as described above (see Fig. S17).

\section{Plasma Cytokine Measurements}

IL-2, IL-4, IL-13, and IFN- $\gamma$ in undiluted plasma samples were quantified by a custom 4-plex rhesus macaque Luminex assay (Thermofisher Scientific) using protocols established by the supplier. ELISA results are reported as the average concentration of duplicate wells extrapolated from a standard curve.

\section{Statistical Analyses}

Spearman's rank correlations were estimated between pre-specified parameters at specific timepoints. Statistical analyses were performed using SAS version 9.4 (Cary, NC, USA). ID50 neutralization titer decline half-life was estimated based on random-effects regression models of decay 
with first-order kinetics $(83,84)$. Models were fit separately by vaccine group and data prior to the second vaccine dose (i.e., from weeks 0 and 4) were excluded. Bi-phasic decline was modeled using a linear spline with one knot (85), with different knots considered ranging from 8 to 18 weeks. For each vaccine group, the model with the knot at 18 weeks fit the best according to the Akaike Information Criterion.

\section{SUPPLEMENTARY MATERIALS}

immunology.sciencemag.org/cgi/content/full/6/60/eabj3684/DC1

Figs. S1 to S17

Tables S1 to S3

\section{REFERENCES AND NOTES}

1. L. R. Baden, H. M. El Sahly, B. Essink, K. Kotloff, S. Frey, R. Novak, D. Diemert, S. A. Spector, N. Rouphael, C. B. Creech, J. McGettigan, S. Khetan, N. Segall, J. Solis, A. Brosz, C. Fierro, H. Schwartz, K. Neuzil, L. Corey, P. Gilbert, H. Janes, D. Follmann, M. Marovich, J. Mascola, L. Polakowski, J. Ledgerwood, B. S. Graham, H. Bennett, R. Pajon, C. Knightly, B. Leav, W. Deng, H. Zhou, S. Han, M. Ivarsson, J. Miller, T. Zaks; COVE Study Group, Efficacy and Safety of the mRNA-1273 SARS-CoV-2 Vaccine. N. Engl. J. Med. 384, 403-416 (2021). doi:10.1056/NEJMoa2035389 Medline

2. A. T. Widge, N. G. Rouphael, L. A. Jackson, E. J. Anderson, P. C. Roberts, M. Makhene, J. D. Chappell, M. R. Denison, L. J. Stevens, A. J. Pruijssers, A. B. McDermott, B. Flach, B. C. Lin, N. A. Doria-Rose, S. O'Dell, S. D. Schmidt, K. M. Neuzil, H. Bennett, B. Leav, M. Makowski, J. Albert, K. Cross, V. V. Edara, K. Floyd, M. S. Suthar, W. Buchanan, C. J. Luke, J. E. Ledgerwood, J. R. Mascola, B. S. Graham, J. H. Beigel; mRNA-1273 Study Group, Durability of Responses after SARS-CoV-2 mRNA-1273 Vaccination. N. Engl. J. Med. 384, 80-82 (2021). doi:10.1056/NEJMc2032195 Medline

3. E. E. Walsh, R. W. Frenck Jr., A. R. Falsey, N. Kitchin, J. Absalon, A. Gurtman, S. Lockhart, K. Neuzil, M. J. Mulligan, R. Bailey, K. A. Swanson, P. Li, K. Koury, W. Kalina, D. Cooper, C. Fontes-Garfias, P. Y. Shi, Ö. Türeci, K. R. Tompkins, K. E. Lyke, V. Raabe, P. R. Dormitzer, K. U. Jansen, U. Şahin, W. C. Gruber, Safety and Immunogenicity of Two RNA-Based Covid-19 Vaccine Candidates. N. Engl. J. Med. 383, 2439-2450 (2020). doi:10.1056/NEJMoa2027906 Medline

4. F. P. Polack, S. J. Thomas, N. Kitchin, J. Absalon, A. Gurtman, S. Lockhart, J. L. Perez, G. Pérez Marc, E. D. Moreira, C. Zerbini, R. Bailey, K. A. Swanson, S. Roychoudhury, K. Koury, P. Li, W. V. Kalina, D. Cooper, R. W. Frenck Jr., L. L. Hammitt, Ö. Türeci, H. Nell, A. Schaefer, S. Ünal, D. B. Tresnan, S. Mather, P. R. Dormitzer, U. Şahin, K. U. Jansen, W. C. Gruber; C4591001 Clinical Trial Group, Safety and Efficacy of the BNT162b2 mRNA Covid-19 Vaccine. N. Engl. J. Med. 383, 2603-2615 (2020). doi:10.1056/NEJMoa2034577 Medline

5. M. Voysey, S. A. C. Clemens, S. A. Madhi, L. Y. Weckx, P. M. Folegatti, P. K. Aley, B. Angus, V. L. Baillie, S. L. Barnabas, Q. E. Bhorat, S. Bibi, C. Briner, P. Cicconi, A. M. Collins, R. Colin-Jones, C. L. Cutland, T. C. Darton, K. Dheda, C. J. A. Duncan, K. R. W. Emary, K. J. Ewer, L. Fairlie, S. N. Faust, S. Feng, D. M. Ferreira, A. Finn, A. L. Goodman, C. M. Green, C. A. Green, P. T. Heath, C. Hill, H. Hill, I. Hirsch, S. H. C. Hodgson, A. Izu, S. Jackson, D. Jenkin, C. C. D. Joe, S. Kerridge, A. Koen, G. Kwatra, R. Lazarus, A. M. Lawrie, A. Lelliott, V. Libri, P. J. Lillie, R. Mallory, A. V. A. Mendes, E. P. Milan, A. M. Minassian, A. McGregor, H. Morrison, Y. F. Mujadidi, A. Nana, P. J. O'Reilly, S. D. Padayachee, A. Pittella, E. Plested, K. M. Pollock, M. N. Ramasamy, S. Rhead, A. V. Schwarzbold, N. Singh, A. Smith, R. Song, M. D. Snape, E. Sprinz, R. K. Sutherland, R. Tarrant, E. C. Thomson, M. E. Török, M. Toshner, D. P. J. Turner, J. Vekemans, T. L. Villafana, M. E. E. Watson, C. J. Williams, A. D. Douglas, A. V. S. Hill, T. Lambe, S. C. Gilbert, A. J. Pollard; Oxford COVID Vaccine Trial Group, Safety and efficacy of the ChAdOx1 nCoV-19 vaccine (AZD1222) against SARS-CoV-2: An interim analysis of four randomised controlled trials in Brazil, South Africa, and the UK. Lancet 397, 99-111 (2021). doi:10.1016/S01406736(20)32661-1 Medline

6. J. Sadoff, M. Le Gars, G. Shukarev, D. Heerwegh, C. Truyers, A. M. de Groot, J. Stoop, S. Tete, W. Van Damme, I. Leroux-Roels, P. J. Berghmans, M. Kimmel, P. Van Damme, J. de Hoon, W. Smith, K. E. Stephenson, S. C. De Rosa, K. W. Cohen, M. J. McElrath, E. Cormier, G. Scheper, D. H. Barouch, J. Hendriks, F. Struyf, M.
Douoguih, J. Van Hoof, H. Schuitemaker, Interim Results of a Phase 1-2a Trial of Ad26.COV2.S Covid-19 Vaccine. N. Engl. J. Med. 384, 1824-1835 (2021). doi:10.1056/NEJMoa2034201 Medline

7. C. Keech, G. Albert, I. Cho, A. Robertson, P. Reed, S. Neal, J. S. Plested, M. Zhu, S. Cloney-Clark, H. Zhou, G. Smith, N. Patel, M. B. Frieman, R. E. Haupt, J. Logue, M. McGrath, S. Weston, P. A. Piedra, C. Desai, K. Callahan, M. Lewis, P. Price-Abbott, N. Formica, V. Shinde, L. Fries, J. D. Lickliter, P. Griffin, B. Wilkinson, G. M. Glenn, Phase 1-2 Trial of a SARS-CoV-2 Recombinant Spike Protein Nanoparticle Vaccine. N. Engl. J. Med. 383, 2320-2332 (2020). doi:10.1056/NEJMoa2026920 Medline

8. M. Guebre-Xabier, N. Patel, J. H. Tian, B. Zhou, S. Maciejewski, K. Lam, A. D. Portnoff, M. J. Massare, M. B. Frieman, P. A. Piedra, L. Ellingsworth, G. Glenn, G. Smith, NVX-CoV2373 vaccine protects cynomolgus macaque upper and lower airways against SARS-CoV-2 challenge. Vaccine 38, 7892-7896 (2020). doi:10.1016/i.vaccine.2020.10.064 Medline

9. K. Singh, S. Mehta, The clinical development process for a novel preventive vaccine: An overview. J. Postgrad. Med. 62, 4-11 (2016). doi:10.4103/0022-3859.173187 Medline

10. L. R. Feldstein, E. B. Rose, A. G. Randolph, Multisystem Inflammatory Syndrome in Children in the United States. Reply. N. Engl. J. Med. 383, 1794-1795 (2020). doi:10.1056/NEJMoa2021680 Medline

11. L. R. Feldstein, E. B. Rose, S. M. Horwitz, J. P. Collins, M. M. Newhams, M. B. F. Son, J. W. Newburger, L. C. Kleinman, S. M. Heidemann, A. A. Martin, A. R. Singh, S. Li, K. M. Tarquinio, P. Jaggi, M. E. Oster, S. P. Zackai, J. Gillen, A. J. Ratner, R. F. Walsh, J. C. Fitzgerald, M. A. Keenaghan, H. Alharash, S. Doymaz, K. N. Clouser, J. S. Giuliano Jr., A. Gupta, R. M. Parker, A. B. Maddux, V. Havalad, S. Ramsingh, H. Bukulmez, T. T. Bradford, L. S. Smith, M. W. Tenforde, C. L. Carroll, B. J. Riggs, S. J. Gertz, A. Daube, A. Lansell, A. Coronado Munoz, C. V. Hobbs, K. L. Marohn, N. B. Halasa, M. M. Patel, A. G. Randolph; Overcoming COVID-19 Investigators; CDC COVID-19 Response Team, Multisystem Inflammatory Syndrome in U.S. Children and Adolescents. N. Engl. J. Med. 383, 334-346 (2020). doi:10.1056/NEJMoa2021680 Medline

12. J. C. McMurray, J. W. May, M. W. Cunningham, O. Y. Jones, Multisystem Inflammatory Syndrome in Children (MIS-C), a Post-viral Myocarditis and Systemic Vasculitis-A Critical Review of Its Pathogenesis and Treatment. Front Pediatr. 8, 626182 (2020). doi:10.3389/fped.2020.626182 Medline

13. P. Y. Lee, M. Day-Lewis, L. A. Henderson, K. G. Friedman, J. Lo, J. E. Roberts, M. S. Lo, C. D. Platt, J. Chou, K. J. Hoyt, A. L. Baker, T. M. Banzon, M. H. Chang, E. Cohen, S. D. de Ferranti, A. Dionne, S. Habiballah, O. Halyabar, J. S. Hausmann, M. M. Hazen, E. Janssen, E. Meidan, R. W. Nelson, A. A. Nguyen, R. P. Sundel, F. Dedeoglu, P. A. Nigrovic, J. W. Newburger, M. B. F. Son, Distinct clinical and immunological features of SARS-CoV-2-induced multisystem inflammatory syndrome in children. J. Clin. Invest. 130, 5942-5950 (2020). doi:10.1172/JCl141113 Medline

14. L. A. Henderson, R. S. M. Yeung, MIS-C: Early lessons from immune profiling. Nat. Rev. Rheumatol. 17, 75-76 (2021). doi:10.1038/s41584-020-00566-y Medline

15. M. E. Van Dyke, M. C. B. Mendoza, W. Li, E. M. Parker, B. Belay, E. M. Davis, J. J. Quint, A. Penman-Aguilar, K. E. N. Clarke, Racial and Ethnic Disparities in COVID19 Incidence by Age, Sex, and Period Among Persons Aged <25 Years - 16 U.S. Jurisdictions, January 1-December 31, 2020. MMWR Morb. Mortal. Wkly. Rep. 70, 382-388 (2021). doi:10.15585/mmwr.mm7011el Medline

16. N. González-García, A. L. Miranda-Lora, J. Garduño-Espinosa, J. T. GranadosRiverón, J. F. Méndez-Galván, J. Nieto-Zermeño, M. F. Castilla-Peón, International heterogeneity in coronavirus disease 2019 pediatric mortality rates. Bol. Méd. Hosp. Infant. México 78, 24-28 (2021). doi:10.24875/BMHIM.20000291 Medline

17. R. M. Viner, O. T. Mytton, C. Bonell, G. J. Melendez-Torres, J. Ward, L. Hudson, C. Waddington, J. Thomas, S. Russell, F. van der Klis, A. Koirala, S. Ladhani, J. Panovska-Griffiths, N. G. Davies, R. Booy, R. M. Eggo, Susceptibility to SARS-CoV2 Infection Among Children and Adolescents Compared With Adults: A Systematic Review and Meta-analysis. JAMA Pediatr. 175, 143-156 (2021). doi:10.1001/jamapediatrics.2020.4573 Medline

18. R. Laxminarayan, B. Wahl, S. R. Dudala, K. Gopal, C. Mohan B, S. Neelima, K. S. Jawahar Reddy, J. Radhakrishnan, J. A. Lewnard, Epidemiology and transmission dynamics of COVID-19 in two Indian states. Science 370, 691-697 (2020). doi:10.1126/science.abd7672 Medline 
19. Hippich M, Holthaus L, Assfalg R, Zapardiel-Gonzalo J, Kapfelsperger H, Heigermoser M, Haupt F, Ewald DA, Welzhofer TC, Marcus BA, Heck S, Koelln A, Stock J, Voss F, Secchi M, Piemonti L, de la Rosa K, Protzer U, Boehmer M, Achenbach P, Lampasona V, Bonifacio E, Ziegler AG. A Public Health Antibody Screening Indicates a 6-Fold Higher SARS-CoV-2 Exposure Rate than Reported Cases in Children. Med (N Y). 2021;2(2):149-63 e4.

20. Hippich M, Sifft P, Zapardiel-Gonzalo J, Bohmer MM, Lampasona V, Bonifacio E, Ziegler AG. A Public Health Antibody Screening Indicates a Marked Increase of SARS-CoV-2 Exposure Rate in Children during the Second Wave. Med (N Y). 2021. Epub 2021/04/13. doi: 10.1016/i.medi.2021.03.019. PubMed PMID: 33842906; PMCID: PMC8018829.

21. S. W. Patrick, L. E. Henkhaus, J. S. Zickafoose, K. Lovell, A. Halvorson, S. Loch, M. Letterie, M. M. Davis, Well-being of Parents and Children During the COVID-19 Pandemic: A National Survey. Pediatrics 146, e2020016824 (2020). doi:10.1542/peds.2020-016824 Medline

22. Loades ME, Chatburn E, Higson-Sweeney N, Reynolds S, Shafran R, Brigden A, Linney C, McManus MN, Borwick C, Crawley E. Rapid Systematic Review: The Impact of Social Isolation and Loneliness on the Mental Health of Children and Adolescents in the Context of COVID-19. J Am Acad Child Adolesc Psychiatry. 2020;59(11):1218-39 e3.

23. F. America, The impact of coronavirus on food insecurity in 2021 and 2021 www.feedingamerica.org2021 [cited 2021 April 3].

24. D. M. Cooper, B. Afghani, C. L. Byington, C. K. Cunningham, S. Golub, K. D. Lu, S. Radom-Aizik, L. F. Ross, J. Singh, W. E. Smoyer, C. T. Lucas, J. Tunney, F. Zaldivar, E. R. Ulloa, SARS-CoV-2 vaccine testing and trials in the pediatric population: Biologic, ethical, research, and implementation challenges. Pediatr. Res. (2021). doi:10.1038/s41390-021-01402-z Medline

25. Mintz K, Jardas E, Shah S, Grady C, Danis M, Wendler D. Enrolling Minors in COVID19 Vaccine Trials. Pediatrics. 2021:147(3). Epub 2020/12/19. doi: 10.1542/peds.2020-040717. PubMed PMID: 33334920; PMCID: PMC7919110 conflicts of interest to disclose.

26. S. Kamidani, C. A. Rostad, E. J. Anderson, COVID-19 vaccine development: A pediatric perspective. Curr. Opin. Pediatr. 33, 144-151 (2021). doi:10.1097/MOP.0000000000000978 Medline

27. E. J. Anderson, J. D. Campbell, C. B. Creech, R. Frenck, S. Kamidani, F. M. Munoz, S. Nachman, P. Spearman, Warp Speed for COVID-19 Vaccines: Why are Children Stuck in Neutral? Clin. Infect. Dis. ciaa1425 (2020). doi:10.1093/cid/ciaa1425 Medline

28. M. PrabhuDas, B. Adkins, H. Gans, C. King, O. Levy, O. Ramilo, C. A. Siegrist, Challenges in infant immunity: Implications for responses to infection and vaccines. Nat. Immunol. 12, 189-194 (2011). doi:10.1038/ni0311-189 Medline

29. R. Rappuoli, Glycoconjugate vaccines: Principles and mechanisms. Sci. Transl. Med. 10, eaat4615 (2018). doi:10.1126/scitransImed.aat4615 Medline

30. M. O. Ota, J. Vekemans, S. E. Schlegel-Haueter, K. Fielding, H. Whittle, P. H. Lambert, K. P. McAdam, C. A. Siegrist, A. Marchant, Hepatitis B immunisation induces higher antibody and memory Th2 responses in new-borns than in adults. Vaccine 22, 511-519 (2004). doi:10.1016/i.vaccine.2003.07.020 Medline

31. D. K. Singh, B. Singh, S. R. Ganatra, M. Gazi, J. Cole, R. Thippeshappa, K. J. Alfson, E. Clemmons, O. Gonzalez, R. Escobedo, T. H. Lee, A. Chatterjee, Y. Goez-Gazi, R. Sharan, M. Gough, C. Alvarez, A. Blakley, J. Ferdin, C. Bartley, H. Staples, L. Parodi, J. Callery, A. Mannino, B. Klaffke, P. Escareno, R. N. Platt 2nd, V. Hodara, J. Scordo, S. Gautam, A. G. Vilanova, A. Olmo-Fontanez, A. Schami, A. Oyejide, D. K. Ajithdoss, R. Copin, A. Baum, C. Kyratsous, X. Alvarez, M. Ahmed, B. Rosa, A. Goodroe, J. Dutton, S. Hall-Ursone, P. A. Frost, A. K. Voges, C. N. Ross, K. Sayers, C. Chen, C. Hallam, S. A. Khader, M. Mitreva, T. J. C. Anderson, L. MartinezSobrido, J. L. Patterson, J. Turner, J. B. Torrelles, E. J. Dick Jr., K. Brasky, L. S. Schlesinger, L. D. Giavedoni, R. Carrion Jr., D. Kaushal, Responses to acute infection with SARS-CoV-2 in the lungs of rhesus macaques, baboons and marmosets. Nat. Microbiol. 6, 73-86 (2021). doi:10.1038/s41564-020-00841-4 Medline

32. K. S. Corbett, B. Flynn, K. E. Foulds, J. R. Francica, S. Boyoglu-Barnum, A. P. Werner, B. Flach, S. O'Connell, K. W. Bock, M. Minai, B. M. Nagata, H. Andersen, D. R. Martinez, A. T. Noe, N. Douek, M. M. Donaldson, N. N. Nji, G. S. Alvarado, D. K. Edwards, D. R. Flebbe, E. Lamb, N. A. Doria-Rose, B. C. Lin, M. K. Louder, S. O'Dell, S. D. Schmidt, E. Phung, L. A. Chang, C. Yap, J. M. Todd, L. Pessaint, A. Van Ry, S.
Browne, J. Greenhouse, T. Putman-Taylor, A. Strasbaugh, T. A. Campbell, A. Cook, A. Dodson, K. Steingrebe, W. Shi, Y. Zhang, O. M. Abiona, L. Wang, A. Pegu, E. S. Yang, K. Leung, T. Zhou, I. T. Teng, A. Widge, I. Gordon, L. Novik, R. A. Gillespie, R. J. Loomis, J. I. Moliva, G. Stewart-Jones, S. Himansu, W. P. Kong, M. C. Nason, K. M. Morabito, T. J. Ruckwardt, J. E. Ledgerwood, M. R. Gaudinski, P. D. Kwong, J. R. Mascola, A. Carfi, M. G. Lewis, R. S. Baric, A. McDermott, I. N. Moore, N. J. Sullivan, M. Roederer, R. A. Seder, B. S. Graham, Evaluation of the mRNA-1273 Vaccine against SARS-CoV-2 in Nonhuman Primates. N. Engl. J. Med. 383, 1544-1555 (2020). doi:10.1056/NEJMoa2024671 Medline

33. A. O. Hassan, F. Feldmann, H. Zhao, D. T. Curiel, A. Okumura, T. L. Tang-Huau, J. B. Case, K. Meade-White, J. Callison, J. Lovaglio, P. W. Hanley, D. P. Scott, D. H. Fremont, H. Feldmann, M. S. Diamond, A single intranasal dose of chimpanzee adenovirus-vectored vaccine protects against SARS-CoV-2 infection in rhesus macaques. bioRxiv 2021.01.26.428251 (2021). 10.1101/2021.01.26.428251 Medline

34. K. Wu, A. P. Werner, J. I. Moliva, M. Koch, A. Choi, G. B. E. Stewart-Jones, H. Bennett, S. Boyoglu-Barnum, W. Shi, B. S. Graham, A. Carfi, K. S. Corbett, R. A. Seder, D. K. Edwards, mRNA-1273 vaccine induces neutralizing antibodies against spike mutants from global SARS-CoV-2 variants. bioRxiv 2021.01.25.427948 (2021). 10.1101/2021.01.25.427948 Medline

35. S. P. Graham, R. K. McLean, A. J. Spencer, S. Belij-Rammerstorfer, D. Wright, M. Ulaszewska, J. C. Edwards, J. W. P. Hayes, V. Martini, N. Thakur, C. Conceicao, I. Dietrich, H. Shelton, R. Waters, A. Ludi, G. Wilsden, C. Browning, D. Bialy, S. Bhat, P. Stevenson-Leggett, P. Hollinghurst, C. Gilbride, D. Pulido, K. Moffat, H. Sharpe, E. Allen, V. Mioulet, C. Chiu, J. Newman, A. S. Asfor, A. Burman, S. Crossley, J. Huo, R. J. Owens, M. Carroll, J. A. Hammond, E. Tchilian, D. Bailey, B. Charleston, S. C. Gilbert, T. J. Tuthill, T. Lambe, Evaluation of the immunogenicity of prime-boost vaccination with the replication-deficient viral vectored COVID-19 vaccine candidate ChAd0x1 nCoV-19. NPJ Vaccines. 5, 69 (2020). doi:10.1038/s41541020-00221-3

36. K. Abel, The rhesus macaque pediatric SIV infection model - a valuable tool in understanding infant HIV-1 pathogenesis and for designing pediatric HIV-1 prevention strategies. Curr. HIV Res. 7, 2-11 (2009). doi:10.2174/157016209787048528 Medline

37. G. Yiu, S. M. Thomasy, M. I. Casanova, A. Rusakevich, R. I. Keesler, J. Watanabe, J. Usachenko, A. Singapuri, E. E. Ball, E. Bliss-Moreau, W. Guo, H. Webster, T. Singh, S. Permar, A. Ardeshir, L. L. Coffey, K. K. Van Rompay, Evolution of ocular defects in infant macaques following in utero Zika virus infection. JCl Insight 5, e143947 (2020). doi:10.1172/jci.insight.143947 Medline

38. G. G. Fouda, C. K. Cunningham, E. J. McFarland, W. Borkowsky, P. Muresan, J. Pollara, L. Y. Song, B. E. Liebl, K. Whitaker, X. Shen, N. A. Vandergrift, R. G. Overman, N. L. Yates, M. A. Moody, C. Fry, J. H. Kim, N. L. Michael, M. Robb, P. Pitisuttithum, J. Kaewkungwal, S. Nitayaphan, S. Rerks-Ngarm, H. X. Liao, B. F. Haynes, D. C. Montefiori, G. Ferrari, G. D. Tomaras, S. R. Permar, Infant HIV type 1 gp120 vaccination elicits robust and durable anti-V1V2 immunoglobulin G responses and only rare envelope-specific immunoglobulin A responses. J. Infect. Dis. 211, 508-517 (2015). doi:10.1093/infdis/iiu444 Medline

39. B. Phillips, K. K. A. Van Rompay, J. Rodriguez-Nieves, C. Lorin, M. Koutsoukos, M. Tomai, C. B. Fox, J. Eudailey, M. Dennis, S. M. Alam, M. Hudgens, G. Fouda, J. Pollara, A. Moody, X. Shen, G. Ferrari, S. Permar, K. De Paris, Adjuvant-Dependent Enhancement of HIV Env-Specific Antibody Responses in Infant Rhesus Macaques. J. Virol. 92, e01051-18 (2018). doi:10.1128/JVI.01051-18 Medline

40. A. D. Curtis 2nd, M. Dennis, J. Eudailey, K. L. Walter, K. Cronin, S. M. Alam, N. Choudhary, R. H. Tuck, M. Hudgens, P. A. Kozlowski, J. Pollara, G. Ferrari, K. K. A. Van Rompay, S. Permar, K. De Paris, HIV Env-Specific IgG Antibodies Induced by Vaccination of Neonatal Rhesus Macaques Persist and Can Be Augmented by a Late Booster Immunization in Infancy. MSphere 5, e00162-20 (2020). doi:10.1128/mSphere.00162-20 Medline

41. K. S. Corbett, M. C. Nason, B. Flach, M. Gagne, S. O' Connell, T. S. Johnston, S. N. Shah, V. V. Edara, K. Floyd, L. Lai, C. McDanal, J. R. Francica, B. Flynn, K. Wu, A. Choi, M. Koch, O. M. Abiona, A. P. Werner, G. S. Alvarado, S. F. Andrew, M. M. Donaldson, J. Fintzi, D. R. Flebbe, E. Lamb, A. T. Noe, S. T. Nurmukhambetova, S. J. Provost, A. Cook, A. Dodson, A. Faudree, J. Greenhouse, S. Kar, L. Pessaint, M. Porto, K. Steingrebe, D. Valentin, S. Zouantcha, K. W. Bock, M. Minai, B. M. Nagata, J. I. Moliva, R. van de Wetering, S. Boyoglu-Barnum, K. Leung, W. Shi, E. S. Yang, 
Y. Zhang, J. M. Todd, L. Wang, H. Andersen, K. E. Foulds, D. K. Edwards, J. R. Mascola, I. N. Moore, M. G. Lewis, A. Carfi, D. Montefiori, M. S. Suthar, A. McDermott, N. J. Sullivan, M. Roederer, D. C. Douek, B. S. Graham, R. A. Seder, Immune Correlates of Protection by mRNA-1273 Immunization against SARSCoV-2 Infection in Nonhuman Primates. bioRxiv 2021.04.20.440647 (2021). 10.1101/2021.04.20.440647 Medline

42. E. J. Anderson, N. G. Rouphael, A. T. Widge, L. A. Jackson, P. C. Roberts, M. Makhene, J. D. Chappell, M. R. Denison, L. J. Stevens, A. J. Pruijssers, A. B. McDermott, B. Flach, B. C. Lin, N. A. Doria-Rose, S. O'Dell, S. D. Schmidt, K. S. Corbett, P. A. Swanson 2nd, M. Padilla, K. M. Neuzil, H. Bennett, B. Leav, M. Makowski, J. Albert, K. Cross, V. V. Edara, K. Floyd, M. S. Suthar, D. R. Martinez, R. Baric, W. Buchanan, C. J. Luke, V. K. Phadke, C. A. Rostad, J. E. Ledgerwood, B. S. Graham, J. H. Beigel; mRNA-1273 Study Group, Safety and Immunogenicity of SARS-CoV-2 mRNA-1273 Vaccine in Older Adults. N. Engl. J. Med. 383, 24272438 (2020). doi:10.1056/NEJMoa2028436 Medline

43. L. A. Jackson, E. J. Anderson, N. G. Rouphael, P. C. Roberts, M. Makhene, R. N. Coler, M. P. McCullough, J. D. Chappell, M. R. Denison, L. J. Stevens, A. J. Pruijssers, A. McDermott, B. Flach, N. A. Doria-Rose, K. S. Corbett, K. M. Morabito, S. O'Dell, S. D. Schmidt, P. A. Swanson 2nd, M. Padilla, J. R. Mascola, K. M. Neuzil, H. Bennett, W. Sun, E. Peters, M. Makowski, J. Albert, K. Cross, W. Buchanan, R. Pikaart-Tautges, J. E. Ledgerwood, B. S. Graham, J. H. Beigel; mRNA-1273 Study Group, An mRNA Vaccine against SARS-CoV-2 - Preliminary Report. N. Engl. J. Med. 383, 1920-1931 (2020). doi:10.1056/NEJMoa2022483 Medline

44. J. A. Mattison, K. L. Vaughan, An overview of nonhuman primates in aging research. Exp. Gerontol. 94, 41-45 (2017). doi:10.1016/j.exger.2016.12.005 Medline

45. A. J. Haertel, K. Prongay, L. Gao, D. H. Gottlieb, B. Park, Standard growth and diarrhea-associated growth faltering in captive infant rhesus macaques (Macaca mulatta). Am. J. Primatol. 80, e22923 (2018). doi:10.1002/ajp.22923 Medline

46. B. S. Graham, G. S. Henderson, Y. W. Tang, X. Lu, K. M. Neuzil, D. G. Colley, Priming immunization determines Thelper cytokine mRNA expression patterns in lungs of mice challenged with respiratory syncytial virus. J. Immunol. 151, 2032-2040 (1993). Medline

47. H. W. Kim, J. G. Canchola, C. D. Brandt, G. Pyles, R. M. Chanock, K. Jensen, R. H. Parrott, Respiratory syncytial virus disease in infants despite prior administration of antigenic inactivated vaccine. Am. J. Epidemiol. 89, 422-434 (1969). doi:10.1093/oxfordjournals.aje.a120955 Medline

48. K. McMahan, J. Yu, N. B. Mercado, C. Loos, L. H. Tostanoski, A. Chandrashekar, J. Liu, L. Peter, C. Atyeo, A. Zhu, E. A. Bondzie, G. Dagotto, M. S. Gebre, C. JacobDolan, Z. Li, F. Nampanya, S. Patel, L. Pessaint, A. Van Ry, K. Blade, J. YalleyOgunro, M. Cabus, R. Brown, A. Cook, E. Teow, H. Andersen, M. G. Lewis, D. A. Lauffenburger, G. Alter, D. H. Barouch, Correlates of protection against SARSCoV-2 in rhesus macaques. Nature 590, 630-634 (2021). doi:10.1038/s41586020-03041-6 Medline

49. S. Reiss, A. E. Baxter, K. M. Cirelli, J. M. Dan, A. Morou, A. Daigneault, N. Brassard, G. Silvestri, J. P. Routy, C. Havenar-Daughton, S. Crotty, D. E. Kaufmann, Comparative analysis of activation induced marker (AIM) assays for sensitive identification of antigen-specific CD4 T cells. PLOS ONE 12, e0186998 (2017). doi:10.1371/journal.pone.0186998 Medline

50. N. Schmitt, S. E. Bentebibel, H. Ueno, Phenotype and functions of memory Tfh cells in human blood. Trends Immunol. 35, 436-442 (2014). doi:10.1016/i.it.2014.06.002 Medline

51. A. B. Vogel, I. Kanevsky, Y. Che, K. A. Swanson, A. Muik, M. Vormehr, L. M. Kranz, K. C. Walzer, S. Hein, A. Güler, J. Loschko, M. S. Maddur, A. Ota-Setlik, K. Tompkins, J. Cole, B. G. Lui, T. Ziegenhals, A. Plaschke, D. Eisel, S. C. Dany, S. Fesser, S. Erbar, F. Bates, D. Schneider, B. Jesionek, B. Sänger, A. K. Wallisch, Y. Feuchter, H. Junginger, S. A. Krumm, A. P. Heinen, P. Adams-Quack, J. Schlereth, S. Schille, C. Kröner, R. de la Caridad Güimil Garcia, T. Hiller, L. Fischer, R. S. Sellers, S. Choudhary, O. Gonzalez, F. Vascotto, M. R. Gutman, J. A. Fontenot, S. Hall-Ursone, K. Brasky, M. C. Griffor, S. Han, A. A. H. Su, J. A. Lees, N. L. Nedoma, E. H. Mashalidis, P. V. Sahasrabudhe, C. Y. Tan, D. Pavliakova, G. Singh, C. FontesGarfias, M. Pride, I. L. Scully, T. Ciolino, J. Obregon, M. Gazi, R. Carrion Jr., K. J. Alfson, W. V. Kalina, D. Kaushal, P. Y. Shi, T. Klamp, C. Rosenbaum, A. N. Kuhn, Ö. Türeci, P. R. Dormitzer, K. U. Jansen, U. Sahin, BNT162b vaccines protect rhesus macaques from SARS-CoV-2. Nature 592, 283-289 (2021). doi:10.1038/s41586- 021-03275-y Medline

52. N. van Doremalen, T. Lambe, A. Spencer, S. Belij-Rammerstorfer, J. N. Purushotham, J. R. Port, V. A. Avanzato, T. Bushmaker, A. Flaxman, M. Ulaszewska, F. Feldmann, E. R. Allen, H. Sharpe, J. Schulz, M. Holbrook, A. Okumura, K. Meade-White, L. Pérez-Pérez, N. J. Edwards, D. Wright, C. Bissett, C. Gilbride, B. N. Williamson, R. Rosenke, D. Long, A. Ishwarbhai, R. Kailath, L. Rose, S. Morris, C. Powers, J. Lovaglio, P. W. Hanley, D. Scott, G. Saturday, E. de Wit, S. C. Gilbert, V. J. Munster, ChAdOx1 nCoV-19 vaccine prevents SARS-CoV-2 pneumonia in rhesus macaques. Nature 586, 578-582 (2020). doi:10.1038/s41586-020-2608-y Medline

53. D. J. Dowling, S. D. van Haren, A. Scheid, I. Bergelson, D. Kim, C. J. Mancuso, W. Foppen, A. Ozonoff, L. Fresh, T. B. Theriot, A. A. Lackner, R. N. Fichorova, D. Smirnov, J. P. Vasilakos, J. M. Beaurline, M. A. Tomai, C. C. Midkiff, X. Alvarez, J. L. Blanchard, M. H. Gilbert, P. P. Aye, O. Levy, TLR7/8 adjuvant overcomes newborn hyporesponsiveness to pneumococcal conjugate vaccine at birth. $\mathrm{JCl}$ Insight 2, e91020 (2017). doi:10.1172/jci.insight.91020 Medline

54. B. Isho, K. T. Abe, M. Zuo, A. J. Jamal, B. Rathod, J. H. Wang, Z. Li, G. Chao, O. L. Rojas, Y. M. Bang, A. Pu, N. Christie-Holmes, C. Gervais, D. Ceccarelli, P. Samavarchi-Tehrani, F. Guvenc, P. Budylowski, A. Li, A. Paterson, F. Y. Yue, L. M. Marin, L. Caldwell, J. L. Wrana, K. Colwill, F. Sicheri, S. Mubareka, S. D. Gray-Owen, S. J. Drews, W. L. Siqueira, M. Barrios-Rodiles, M. Ostrowski, J. M. Rini, Y. Durocher, A. J. McGeer, J. L. Gommerman, A. C. Gingras, Persistence of serum and saliva antibody responses to SARS-CoV-2 spike antigens in COVID-19 patients. Sci. Immunol. 5, eabe5511 (2020). Medline

55. M. Gleeson, A. W. Cripps, Development of mucosal immunity in the first year of life and relationship to sudden infant death syndrome. FEMS Immunol. Med. Microbiol. 42. 21-33 (2004). doi:10.1016/i.femsim.2004.06.012 Medline

56. T. Rogosch, S. Kerzel, K. Hoss, G. Hoersch, C. Zemlin, M. Heckmann, C. Berek, H. W. Schroeder Jr., R. F. Maier, M. Zemlin, IgA response in preterm neonates shows little evidence of antigen-driven selection. J. Immunol. 189, 5449-5456 (2012). doi:10.4049/iimmunol.1103347 Medline

57. K. Jensen, R. Nabi, K. K. A. Van Rompay, S. Robichaux, J. D. Lifson, M. Piatak Jr., W. R. Jacobs Jr., G. Fennelly, D. Canfield, K. R. Mollan, M. G. Hudgens, M. H. Larsen, A. M. Amedee, P. A. Kozlowski, K. De Paris, Vaccine-Elicited Mucosal and Systemic Antibody Responses Are Associated with Reduced Simian Immunodeficiency Viremia in Infant Rhesus Macaques. J. Virol. 90, 7285-7302 (2016). doi:10.1128/JVI.00481-16 Medline

58. D. S. Khoury, D. Cromer, A. Reynaldi, T. E. Schlub, A. K. Wheatley, J. A. Juno, K. Subbarao, S. J. Kent, J. A. Triccas, M. P. Davenport, Neutralizing antibody levels are highly predictive of immune protection from symptomatic SARS-CoV-2 infection. Nat. Med. (2021). doi:10.1038/s41591-021-01377-8 Medline

59. K. A. Earle, D. M. Ambrosino, A. J. Fiore-Gartland, D. Goldblatt, P. B. Gilbert, G. R. Siber, P. Dull, S. A. Plotkin, Evidence for antibody as protective correlate for COVID-19 vaccines. bioRxiv (2021). 10.1101/2021.03.17.20200246

60. I. Debock, V. Flamand, Unbalanced Neonatal CD4(+) T-Cell Immunity. Front. Immunol. 5, 393 (2014). doi:10.3389/fimmu.2014.00393 Medline

61. M. E. Bottazzi, U. Strych, P. J. Hotez, D. B. Corry, Coronavirus vaccine-associated lung immunopathology-what is the significance? Microbes Infect. 22, 403-404 (2020). doi:10.1016/i.micinf.2020.06.007 Medline

62. D. Deming, T. Sheahan, M. Heise, B. Yount, N. Davis, A. Sims, M. Suthar, J. Harkema, A. Whitmore, R. Pickles, A. West, E. Donaldson, K. Curtis, R. Johnston, $R$. Baric, Vaccine efficacy in senescent mice challenged with recombinant SARSCoV bearing epidemic and zoonotic spike variants. PLOS Med. 3, e525 (2006). doi:10.1371/journal.pmed.0030525 Medline

63. T. Bilich, A. Nelde, J. S. Heitmann, Y. Maringer, M. Roerden, J. Bauer, J. Rieth, M. Wacker, A. Peter, S. Hörber, D. Rachfalski, M. Märklin, S. Stevanović, H. G. Rammensee, H. R. Salih, J. S. Walz, T cell and antibody kinetics delineate SARSCoV-2 peptides mediating long-term immune responses in COVID-19 convalescent individuals. Sci. Transl. Med. 13, eabf7517 (2021). doi:10.1126/scitranslmed.abf7517 Medline

64. Sekine T, Perez-Potti A, Rivera-Ballesteros 0, Stralin K, Gorin JB, Olsson A, Llewellyn-Lacey S, Kamal H, Bogdanovic G, Muschiol S, Wullimann DJ, Kammann T, Emgard J, Parrot T, Folkesson E, Karolinska C-SG, Rooyackers O, Eriksson LI, Henter JI, Sonnerborg A, Allander T, Albert J, Nielsen M, Klingstrom J, GredmarkRuss S, Bjorkstrom NK, Sandberg JK, Price DA, Ljunggren HG, Aleman S, Buggert 
M. Robust T Cell Immunity in Convalescent Individuals with Asymptomatic or Mild COVID-19. Cell. 2020;183(1):158-68 e14.

65. S. Bélanger, S. Crotty, Dances with cytokines, featuring TFH cells, IL-21, IL-4 and B cells. Nat. Immunol. 17, 1135-1136 (2016). doi:10.1038/ni.3561 Medline

66. G. E. Hartley, E. S. J. Edwards, P. M. Aui, N. Varese, S. Stojanovic, J. McMahon, A. Y. Peleg, I. Boo, H. E. Drummer, P. M. Hogarth, R. E. O'Hehir, M. C. van Zelm, Rapid generation of durable B cell memory to SARS-CoV-2 spike and nucleocapsid proteins in COVID-19 and convalescence. Sci. Immunol. 5, eabf8891 (2020). doi:10.1126/sciimmunol.abf8891 Medline

67. O. Levy, E. E. Suter, R. L. Miller, M. R. Wessels, Unique efficacy of Toll-like receptor 8 agonists in activating human neonatal antigen-presenting cells. Blood 108 1284-1290 (2006). doi:10.1182/blood-2005-12-4821 Medline

68. Philbin VJ, Dowling DJ, Gallington LC, Cortes G, Tan Z, Suter EE, Chi KW, Shuckett A, Stoler-Barak L, Tomai M, Miller RL, Mansfield K, Levy O. Imidazoquinoline Tolllike receptor 8 agonists activate human newborn monocytes and dendritic cells through adenosine-refractory and caspase-1-dependent pathways. J Allergy Clin Immunol. 2012;130(1):195-204 e9.

69. D. J. Dowling, Z. Tan, Z. M. Prokopowicz, C. D. Palmer, M. A. Matthews, G. N Dietsch, R. M. Hershberg, O. Levy, The ultra-potent and selective TLR8 agonist VTX-294 activates human newborn and adult leukocytes. PLOS ONE 8, e58164 (2013). doi:10.1371/journal.pone.0058164 Medline

70. J. W. Upham, P. T. Lee, B. J. Holt, T. Heaton, S. L. Prescott, M. J. Sharp, P. D. Sly, P. G. Holt, Development of interleukin-12-producing capacity throughout childhood. Infect. Immun. 70, 6583-6588 (2002). doi:10.1128/IAl.70.12.65836588.2002 Medline

71. Data. OWi. Number of births and death per year, world University of Oxford2021 [cited 2021 May 28, 2021].

72. A. D. Curtis 2nd, K. Jensen, K. K. A. Van Rompay, R. R. Amara, P. A. Kozlowski, K. De Paris, A simultaneous oral and intramuscular prime/sublingual boost with a DNA/Modified Vaccinia Ankara viral vector-based vaccine induces simian immunodeficiency virus-specific systemic and mucosal immune responses in juvenile rhesus macaques. J. Med. Primatol. 47, 288-297 (2018). doi:10.1111/imp.12372 Medline

73. D. Wrapp, N. Wang, K. S. Corbett, J. A. Goldsmith, C. L. Hsieh, O. Abiona, B. S. Graham, J. S. McLellan, Cryo-EM structure of the 2019-nCoV spike in the prefusion conformation. Science 367, 1260-1263 (2020). doi:10.1126/science.abb2507 Medline

74. M. Dennis, J. Eudailey, J. Pollara, A. S. McMillan, K. D. Cronin, P. T. Saha, A. D. Curtis, M. G. Hudgens, G. G. Fouda, G. Ferrari, M. Alam, K. K. A. Van Rompay, K. De Paris, S. Permar, X. Shen, Co-administration of $\mathrm{CH} 31$ broadly neutralizing antibody does not affect development of vaccine-induced anti-HIV-1 envelope antibody responses in infant Rhesus macaques. J. Virol. 93, e01783-e18 (2019). Medline

75. P. A. Kozlowski, R. M. Lynch, R. R. Patterson, S. Cu-Uvin, T. P. Flanigan, M. R. Neutra, Modified wick method using Weck-Cel sponges for collection of human rectal secretions and analysis of mucosal HIV antibody. J. Acquir. Immune Defic. Syndr. 24, 297-309 (2000). doi:10.1097/00126334-200008010-00001 Medline

76. B. Phillips, G. G. Fouda, J. Eudailey, J. Pollara, A. D. Curtis 2nd, E. Kunz, M. Dennis, X. Shen, C. Bay, M. Hudgens, D. Pickup, S. M. Alam, A. Ardeshir, P. A. Kozlowski, K. K. A. Van Rompay, G. Ferrari, M. A. Moody, S. Permar, K. De Paris, Impact of Poxvirus Vector Priming, Protein Coadministration, and Vaccine Intervals on HIV gp120 Vaccine-Elicited Antibody Magnitude and Function in Infant Macaques. Clin. Vaccine Immunol. 24, e00231-17 (2017). doi:10.1128/CVI.00231-17 Medline

77. Y. Shaan Lakshmanappa, S. R. Elizaldi, J. W. Roh, B. A. Schmidt, T. D. Carroll, K. D. Weaver, J. C. Smith, A. Verma, J. D. Deere, J. Dutra, M. Stone, S. Franz, R. L. Sammak, K. J. Olstad, J. Rachel Reader, Z. M. Ma, N. K. Nguyen, J. Watanabe, J. Usachenko, R. Immareddy, J. L. Yee, D. Weiskopf, A. Sette, D. Hartigan-O'Connor, S. J. McSorley, J. H. Morrison, N. K. Tran, G. Simmons, M. P. Busch, P. A. Kozlowski, K. K. A. Van Rompay, C. J. Miller, S. S. lyer, SARS-CoV-2 induces robust germinal center CD4 T follicular helper cell responses in rhesus macaques. Nat. Commun. 12, 541 (2021). doi:10.1038/s41467-020-20642-x Medline

78. L. Naldini, U. Blömer, P. Gallay, D. Ory, R. Mulligan, F. H. Gage, I. M. Verma, D. Trono, In vivo gene delivery and stable transduction of nondividing cells by a lentiviral vector. Science 272, 263-267 (1996). doi:10.1126/science.272.5259.263 Medline
79. Y. J. Hou, S. Chiba, P. Halfmann, C. Ehre, M. Kuroda, K. H. Dinnon 3rd, S. R. Leist, A. Schäfer, N. Nakajima, K. Takahashi, R. E. Lee, T. M. Mascenik, C. E. Edwards, L. V. Tse, R. C. Boucher, S. H. Randell, T. Suzuki, L. E. Gralinski, Y. Kawaoka, R. S. Baric, SARS-CoV-2 D614G Variant Exhibits Enhanced Replication ex vivo and Earlier Transmission in vivo. bioRxiv 2020.09.28.317685 (2020). 10.1101/2020.09.28.317685 Medline

80. J. R. Whittle, R. Zhang, S. Khurana, L. R. King, J. Manischewitz, H. Golding, P. R. Dormitzer, B. F. Haynes, E. B. Walter, M. A. Moody, T. B. Kepler, H. X. Liao, S. C. Harrison, Broadly neutralizing human antibody that recognizes the receptorbinding pocket of influenza virus hemagglutinin. Proc. Natl. Acad. Sci. U.S.A. 108 14216-14221 (2011). doi:10.1073/pnas.1111497108 Medline

81. A. D. Curtis 2nd, K. A. Walter, R. Nabi, K. Jensen, A. Dwivedi, J. Pollara, G. Ferrari, K. K. A. Van Rompay, R. R. Amara, P. A. Kozlowski, K. De Paris, Oral Coadministration of an Intramuscular DNA/Modified Vaccinia Ankara Vaccine for Simian Immunodeficiency Virus Is Associated with Better Control of Infection in Orally Exposed Infant Macaques. AIDS Res. Hum. Retroviruses 35, 310-325 (2019). doi:10.1089/aid.2018.0180 Medline

82. J. M. Dan, C. S. Lindestam Arlehamn, D. Weiskopf, R. da Silva Antunes, C. HavenarDaughton, S. M. Reiss, M. Brigger, M. Bothwell, A. Sette, S. Crotty, A CytokineIndependent Approach To Identify Antigen-Specific Human Germinal Center T Follicular Helper Cells and Rare Antigen-Specific CD4+ T Cells in Blood. J. Immunol. 197, 983-993 (2016). doi:10.4049/jimmunol.1600318 Medline

83. D. Finzi, J. Blankson, J. D. Siliciano, J. B. Margolick, K. Chadwick, T. Pierson, K. Smith, J. Lisziewicz, F. Lori, C. Flexner, T. C. Quinn, R. E. Chaisson, E. Rosenberg, B. Walker, S. Gange, J. Gallant, R. F. Siliciano, Latent infection of CD4+ T cells provides a mechanism for lifelong persistence of HIV-1, even in patients on effective combination therapy. Nat. Med. 5, 512-517 (1999). doi:10.1038/8394 Medline

84. J. D. Siliciano, J. Kajdas, D. Finzi, T. C. Quinn, K. Chadwick, J. B. Margolick, C. Kovacs, S. J. Gange, R. F. Siliciano, Long-term follow-up studies confirm the stability of the latent reservoir for HIV-1 in resting CD4+ T cells. Nat. Med. 9, 727728 (2003). doi:10.1038/nm880 Medline

85. M. J. Peluso, P. Bacchetti, K. D. Ritter, S. Beg, J. Lai, J. N. Martin, P. W. Hunt, T. J. Henrich, J. D. Siliciano, R. F. Siliciano, G. M. Laird, S. G. Deeks, Differential decay of intact and defective proviral DNA in HIV-1-infected individuals on suppressive antiretroviral therapy. JCl Insight 5, e132997 (2020). doi:10.1172/jci.insight.132997 Medline

Acknowledgments: We thank Jennifer Watanabe, Jodie Usachenko, Ramya Immareddy, the Veterinary staff and Colony Research Services of the California National Primate Research Center for expert assistance. We thank Elise Larson, Ines De Lima, Tony Phan, Susan Lin, and Robert Kinsey from IDRI for technical assistance in preparing and characterizing 3M-052-SE. We thank Jim Giron of ThermoFisher Scientific for expert technical assistance with T cell cytokine Luminex assays. We thank Dr. James Peacock in the Duke Human Vaccine Institute Research Protein Production Facility. Funding: The studies were supported by funding from the National Institutes of Health grant P01 Al11791506S1 to SRP and KDP, and the National Institutes of Health grant U54 CA260543 to RB. The nonhuman primate studies at the CNPRC were supported by the National Institutes of Health Office of Research Infrastructure Program/OD P510D11107. Additional infrastructure support was provided the National Institutes of Health grant UM1 AI068618-15 (HVTN/HPTN, CoVPN), the UNC Center for AIDS Research through the National Institutes of Health grant P30AI050410, and the UNC-LCCC Flow Cytometry Core Facility that is supported by P30 CA016086. Dr. Corbett is the recipient of a research fellowship that was partially funded by the Undergraduate Scholarship Program, Office of Intramural Training and Education, Office of the Director, NIH. Author Contributions: The project was developed by KDP, SRP, BG, DE, AC, MT, and $\mathrm{CBF}$. The vaccine components were supplied by BG, DE, AC, MT, and CBF. The animal studies were conducted by KKAVR, BG, KSC, and OMA. The various assays)methodology) were performed by CG, ADC, MD, SHP, GF, PAK, HG, DM, TS, JEM, MLM, LSL, and RSB. The original manuscript draft was written by CG, $A D C, S R P$, and KDP. Review and editing were performed with the help of $C G$, $A D C, M T, C B F, P A K, R S B, B G, K S C, D E, A C, G F, K K A V R$, SRP, and KDP. The statistical analysis was overseen by PTS and MGH. Competing Interests: A. Carfi, and D. Edwards are employees of Moderna Inc. and hold equities from the 
company. B. S. Graham and K. S. Corbett are inventors on Patent Applications: EP Patent Application 17800655.7 filed 13 May 2019, entitled "Prefusion coronavirus spike proteins and their use"; US Patent Application 16/344,774 filed 24 April 2019 entitled "Prefusion coronavirus spike proteins and their use" [HHS Ref. No. E-234-2016-1-US-03]. O. M. Abiona, B. S. Graham and K. S.

Corbett are inventors on the Patent Application: US Provisional Patent Application 62/972,886 filed 11 February 2020 entitled "2019-nCoV Vaccine". M. Tomai is an employee of $3 \mathrm{M}$, the owner of the adjuvant and owns stock options in this company. C.B. Fox is an inventor on US patent application 2017/032756,

PEGylated Lysosmes and Methods of Use. Dr. Permar has sponsored programs and consults with Merck and Moderna for their CMV vaccine programs. Data and materials availability: All data needed to evaluate the conclusions in the paper are present in the paper of the Supplementary Materials. This work is licensed under a Creative Commons Attribution 4.0 International (CC BY 4.0) license, which permits unrestricted use, distribution, and reproduction in any medium, provided the original work is properly cited. To view a copy of this license, visit https://creativecommons.org/licenses/by/4.0/. This license does not apply to figures/photos/artwork or other content included in the article that is credited to a third party; obtain authorization from the rights holder before using such material.

Submitted 7 May 2021

Accepted 4 June 2021

Published First Release 15 June 2021

10.1126/sciimmunol.abj3684 


$\begin{gathered}\text { Vaccine } \\ \text { (prime) }\end{gathered}$
(boost)

Fig. 1. Study Design: evaluation of immunogenicity of two SARS-CoV-2 vaccines in infant rhesus macaques. Infant rhesus macaques (median age of 2.2 months at study initiation) were immunized at 0 and 4 weeks with either $30 \mu \mathrm{g}$ mRNA encoding S-2P (Vaccine Research Center, $\mathrm{NIH}$ ) in lipid nanoparticles (mRNA-LNP) or $15 \mu \mathrm{g}$ S-2P protein formulated with 3M-052 adjuvant, a TLR7/8 agonist, as a stable emulsion (3M-052-SE). Each group consisted of 8 animals. Blood and saliva samples were collected at weeks $0,4,6,8,14,18$ and 22, and lymph node biopsies were obtained at week 6 . 


\section{A S-specific Plasma IgG}
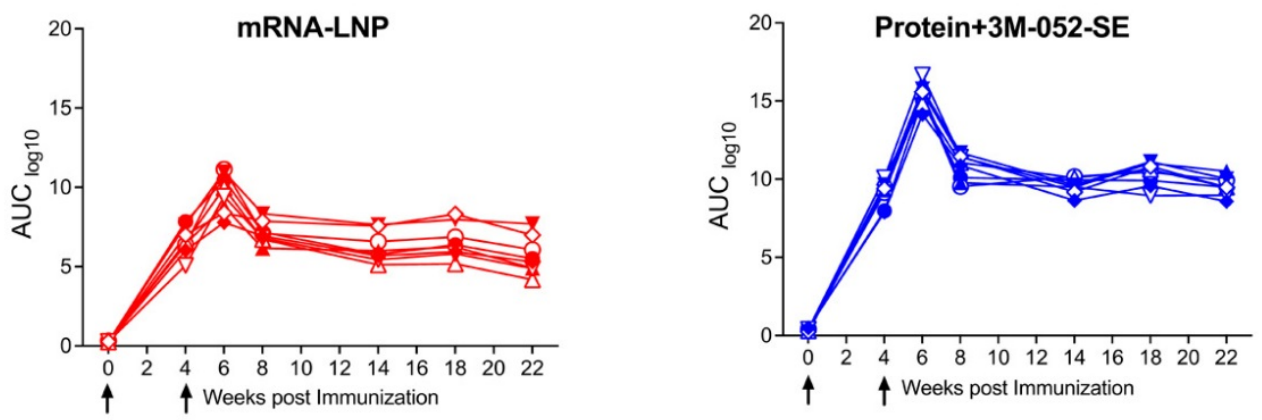

\section{B IgG epitope specificity}

mRNA-LNP
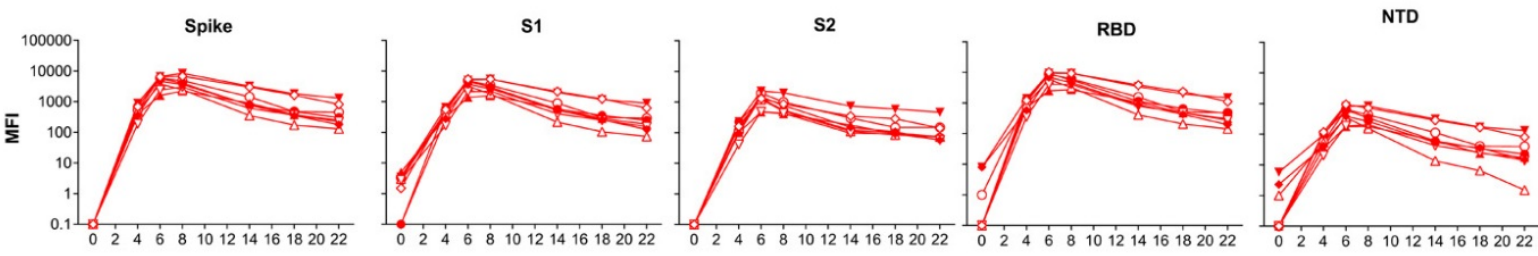

Protein+3M-052-SE
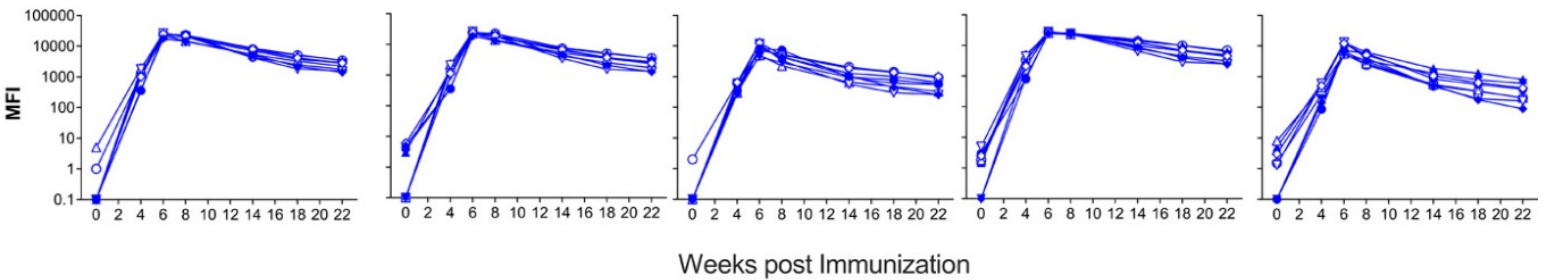

\section{RBD-specific Saliva IgG}
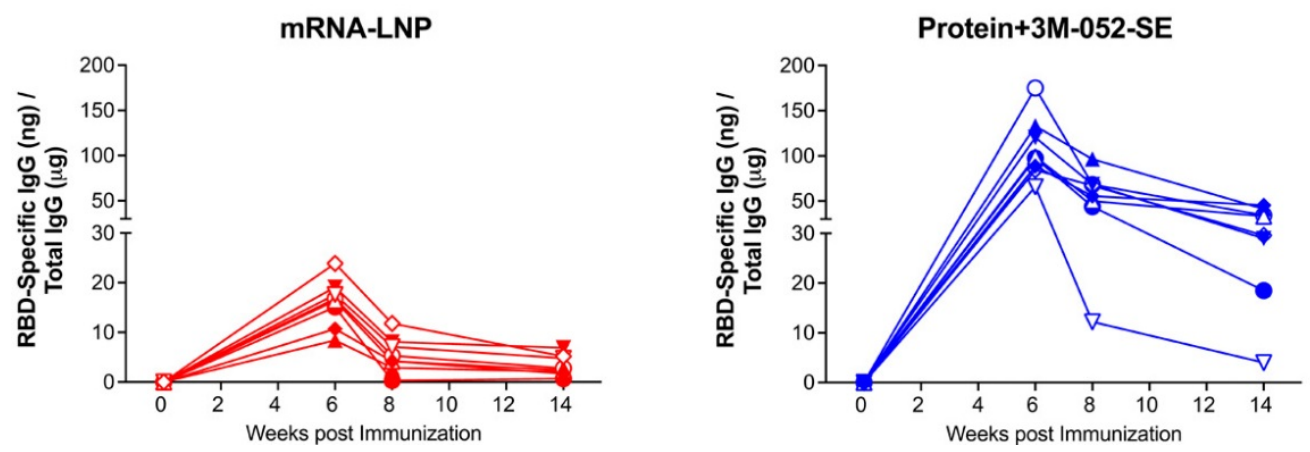

Fig. 2. SARS-CoV-2 vaccine-elicited binding antibody responses in infant rhesus macaques. Plasma and saliva were collected before vaccination (week 0 ), at week 4 - prior to the $2^{\text {nd }}$ dose-, two weeks post $2^{\text {nd }}$ dose (week 6 ), and at weeks 8 , 14, 18 and 22 from infant RM vaccinated with $30 \mu \mathrm{g}$ mRNA encoding S-2P spike protein in lipid nanoparticles ( $\mathrm{n}=8$; red) or with $15 \mu$ g prefusion SARS-CoV-2 S-2P spike protein formulated with 3M-052 adjuvant ( $n=8$; blue). (A): S-2P protein-specific antibody responses were measured by enzyme-linked immunosorbent assay (ELISA). Serial dilutions of plasma starting at 1:40 were assayed for lgG binding to SARS-CoV-2 spike. Data are reported as $\log _{10}$ area under the curve (AUC) values. (B): Antibody epitope specificity measured by BAMA. Plasma was diluted 1:10,000 to measure binding to different domains of the spike protein, including the full-length S protein, S1, RBD, NTD, and S2. Binding antibody responses are reported as $\log _{10}$ transformed mean fluorescence intensity (MFI) after subtraction of background values. (C): Salivary RBD-specific IgG was measured by binding antigen multiplex assay (BAMA) using serial dilutions of saliva and responses are reported as RBDspecific lgG (ng)/ total lgG ( $\mu \mathrm{g})$. Different symbols represent individual animals (Table 1). Arrows in Panel A indicate times of immunizations. 


\section{A ACE2 Blocking mRNA-LNP}

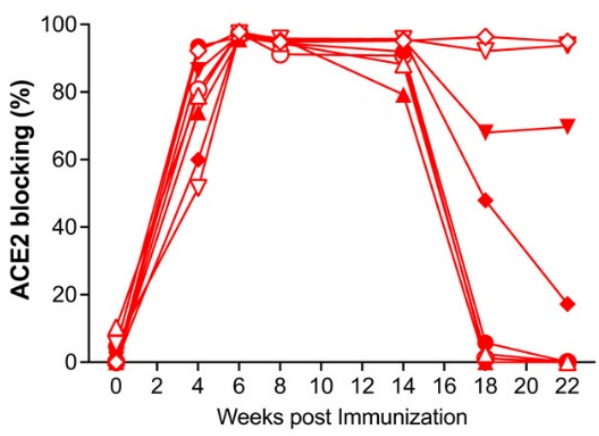

\section{B Pseudovirus Neutralization}

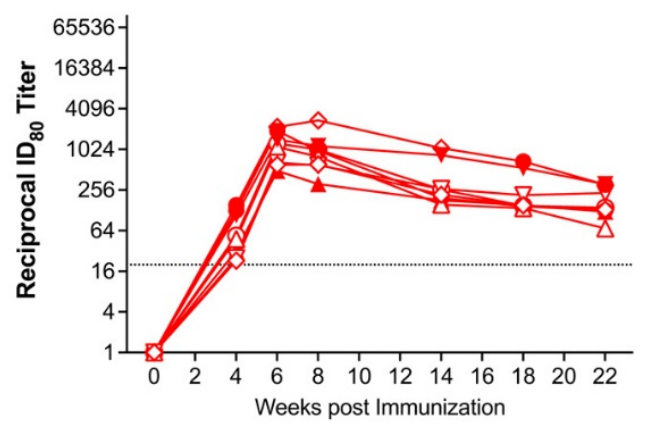

\section{Whole Virion Neutralization}

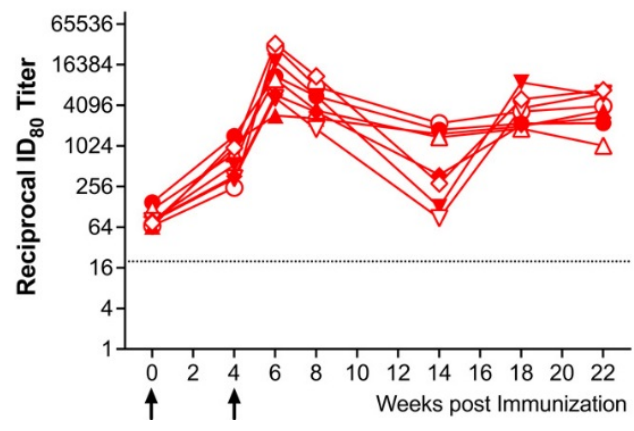

Protein+3M-052-SE
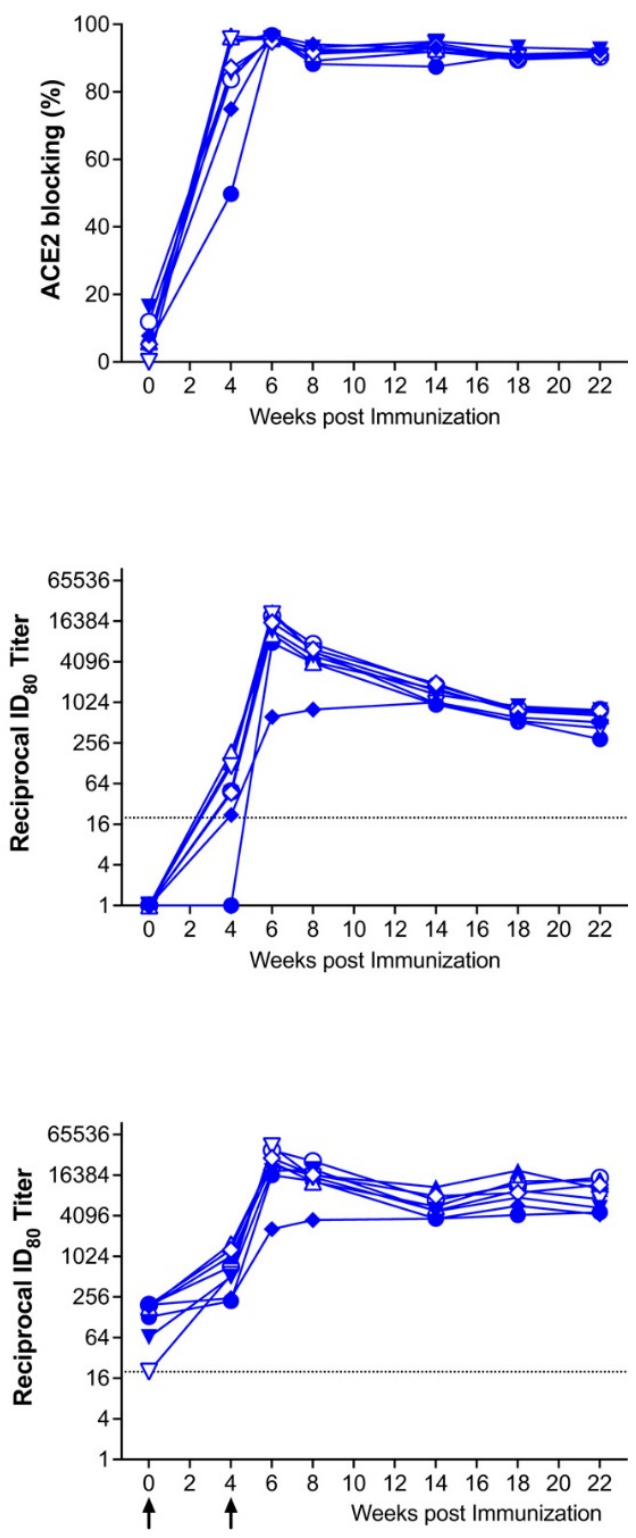

Fig. 3. SARS-CoV-2 vaccine-elicited functional antibody responses in infant rhesus macaques. (A): The capacity of plasma antibodies to mediate blocking of the RBD-ACE2 interaction was measured with an ELISAbased ACE2 blocking assay at 1:10 plasma dilution. Data are reported as \%ACE2 blocking. (B-C): Neutralization capacity was measured using Spike D614G-pseudotyped viruses in 293T/ACE2 cells (B) and whole virus (D614G) assay with Vero E6 cells (C); results are expressed as reciprocal $80 \%$ inhibitory dilution $\left(I_{80}\right)$. Grey dotted lines represent detection cut-off. Different symbols represent individual animals (Table 1). Longitudinal data for each animal in the mRNA-LNP (red) or Protein+3M-052-SE group (blue) are represented by separate lines. Arrows in Panel $\mathrm{C}$ indicate times of immunizations. 

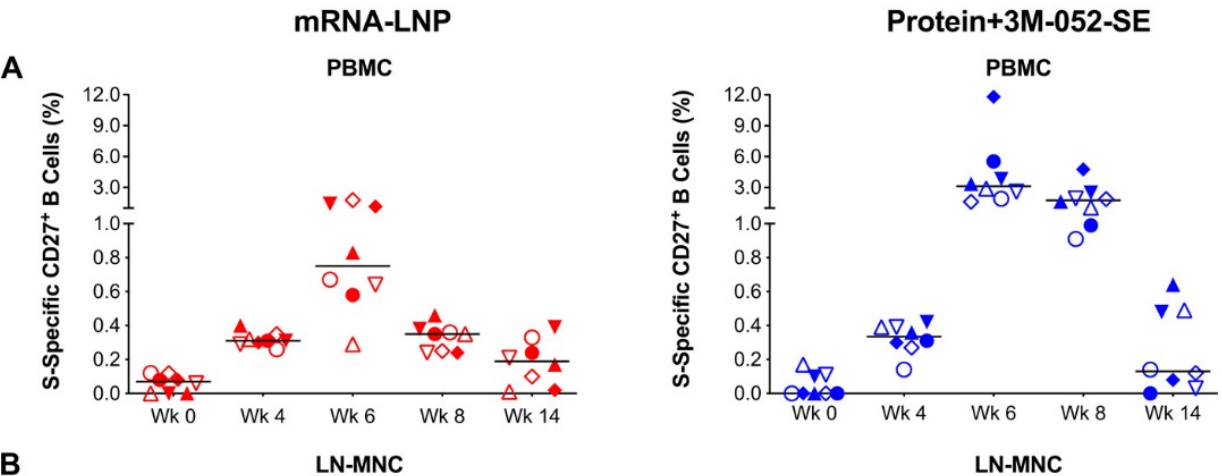

B

LN-MNC
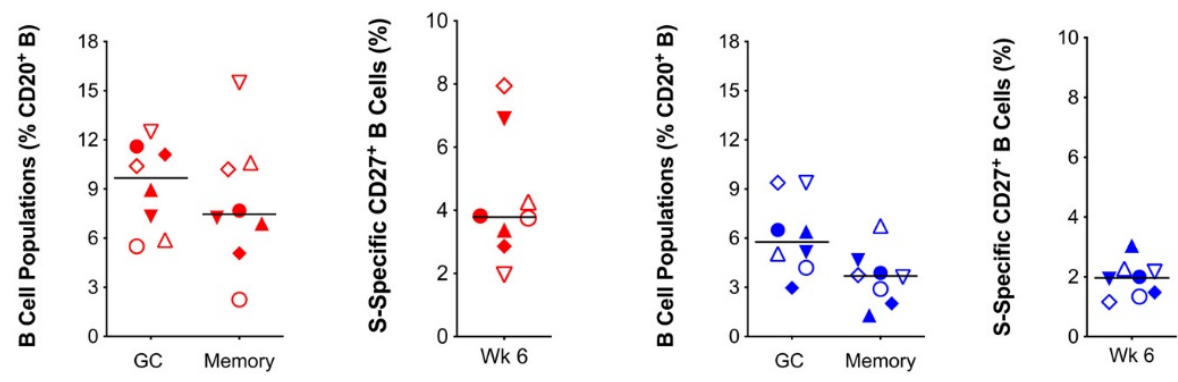

S-Specific Antibody-secreting Cells

C

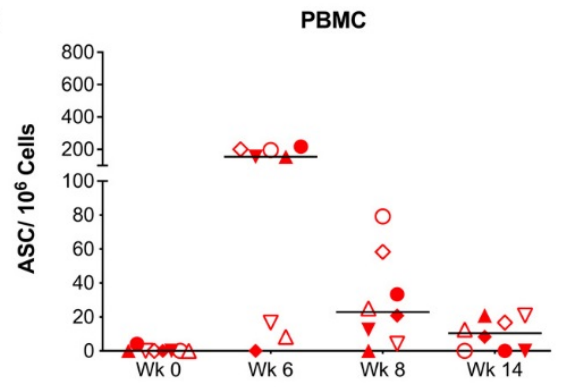

D

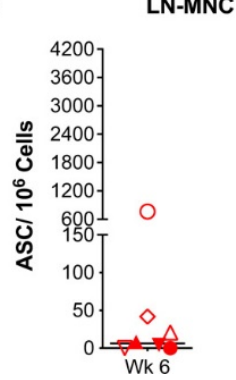

PBMC
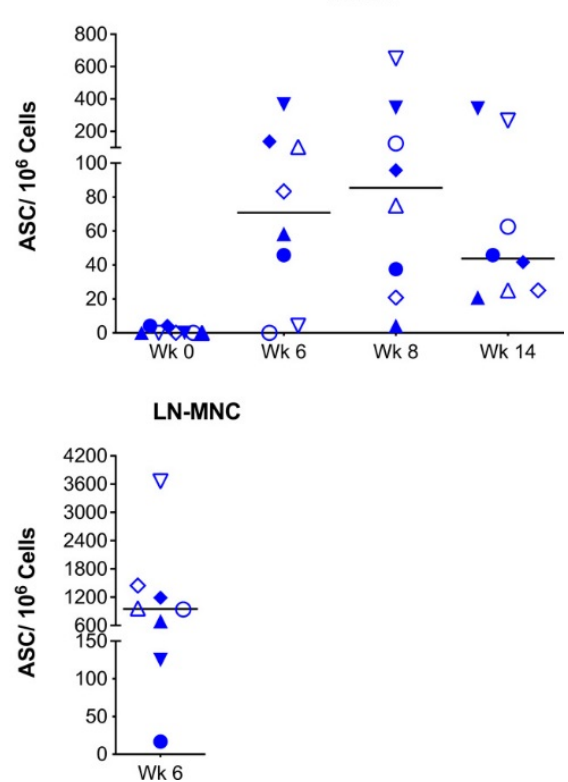

Fig. 4. Characterization of Spike-specific $B$ cell responses two weeks post boost. (A) $C D 20^{+} C D 27^{+}$memory $B$ cells that co-stained with fluorochrome-conjugated SARS-CoV-2 spike protein in mRNA-LNP (red) or Protein+3M-052-SE (blue) vaccinees in blood. Frequencies are expressed as percent of total memory $B$ cells. The gating strategy is provided in Supplementary Figure S14. (B): In lymph nodes, we determined total Bcl- $6{ }^{+} \mathrm{K}_{\mathrm{i}}-67^{+}$Germinal Center (GC) $B$ cells and $C D 27^{+}$memory B cells as percent of total $C D 20^{+} B$ cells (left panel) (see Fig. S15 for gating strategy) and also the percent of S-specific memory B cells (right panel). (C) Antibody secreting cell (ASC) as measured by B cell ELISpot in PBMC from mRNA-LNP or Protein+3M-052-SE vaccinees, while (D) is showing mRNA-LNP and Protein+3M-052-SE ASC responses, respectively, in LN at week 6. Different symbols represent individual animals (Table 1). Solid lines represent median values. 

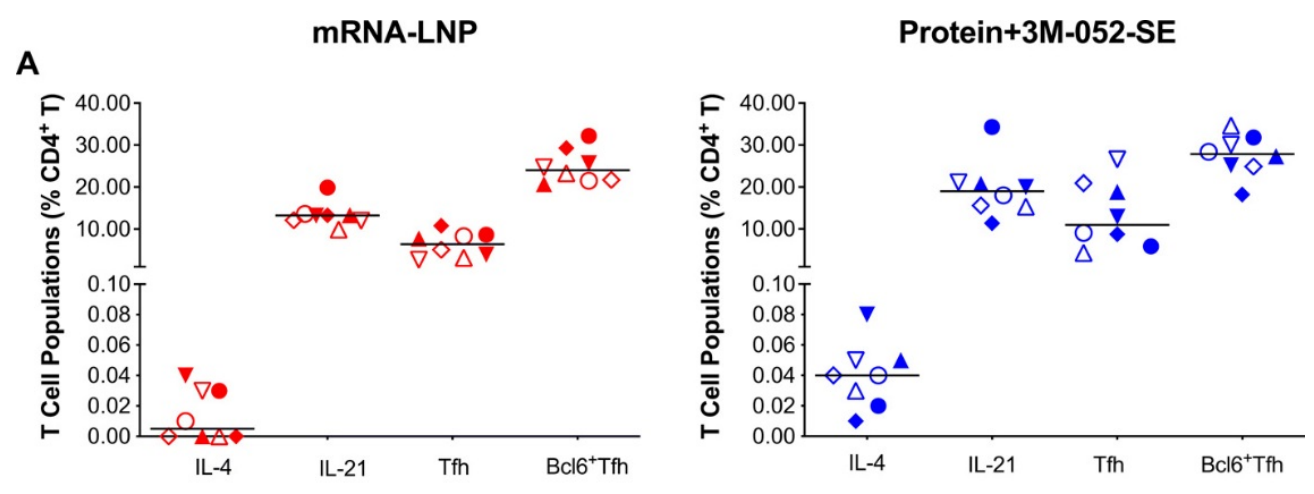

B
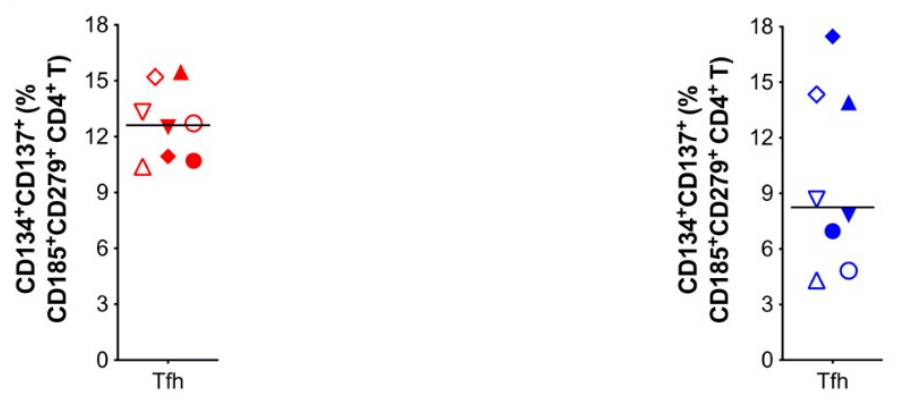

C
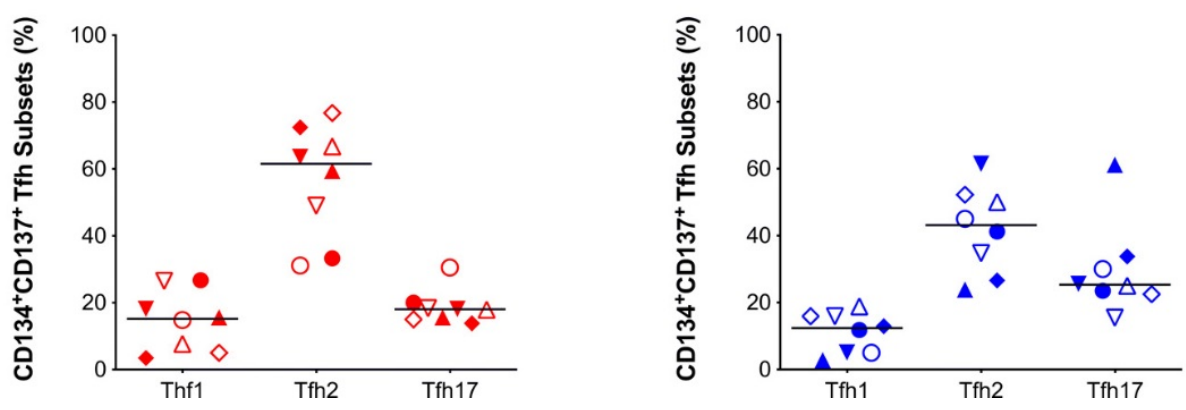

Fig. 5. Immunophenotype of lymph node T cell population two weeks post-boost. (A): CD4 ${ }^{+} \mathrm{T}$-cells positive for IL-4 or IL-21, follicular T helper cell (Tfh) markers CD279/PD-1 and CD185/CXCR5, or Bcl6 ${ }^{+}$Tfh were measured and are represented as percent of total LN CD4 ${ }^{+} \mathrm{T}$ cells. The gating strategy for these panels is provided in Figure S15. (B): SEB activated Tfh frequencies assessed by the Activation-Induced Marker (AIM) Assay: CXCR5 ${ }^{+} \mathrm{CD} 185^{+}$cells that co-expressed CD134 and CD137 for Protein+3M-052-SE and mRNA-LNP, respectively. (C) The frequency of CXCR5 ${ }^{+} \mathrm{CD} 185^{+} \mathrm{CD} 134^{+} \mathrm{CD} 137^{+} \mathrm{CXCR}{ }^{+} \mathrm{CD} 196-{ }^{-}$Th1, $\mathrm{CXCR} 3{ }^{-C C R 6}{ }^{-}$Tfh2 and CXCR3-CD196+ Tfh17 cells is shown. The gating strategy for these populations is given in Fig. S17. Red symbols: mRNA-LNP, blue symbols: Protein+3M-052-SE. Different symbols represent individual animals (Table 1). Solid lines define the median. 


\section{A Week 4}
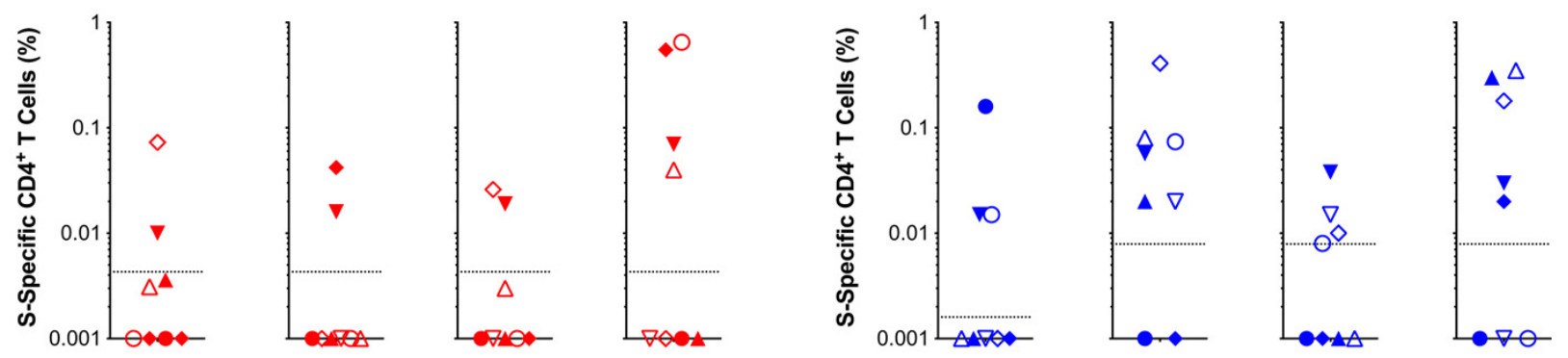

\section{B Week 6}
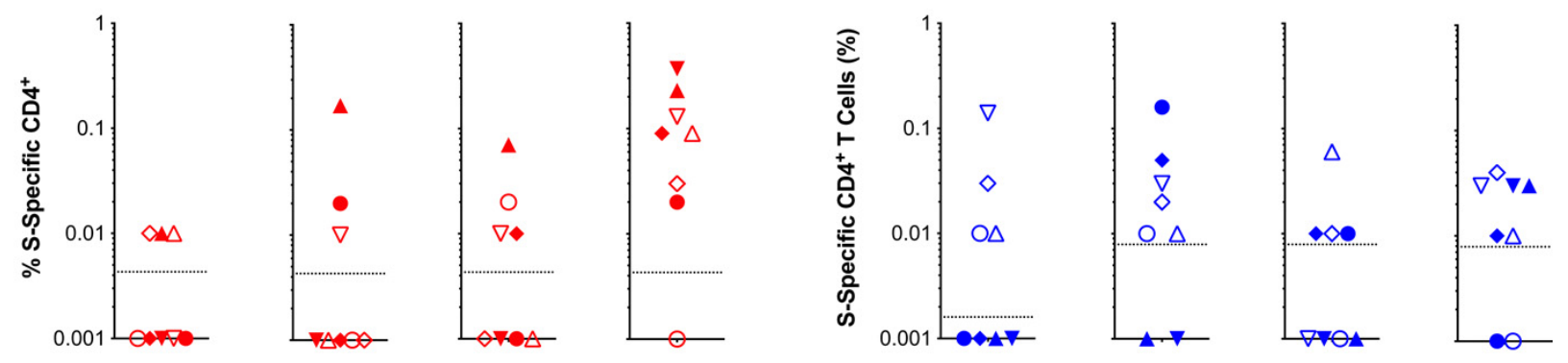

\section{Week 8}
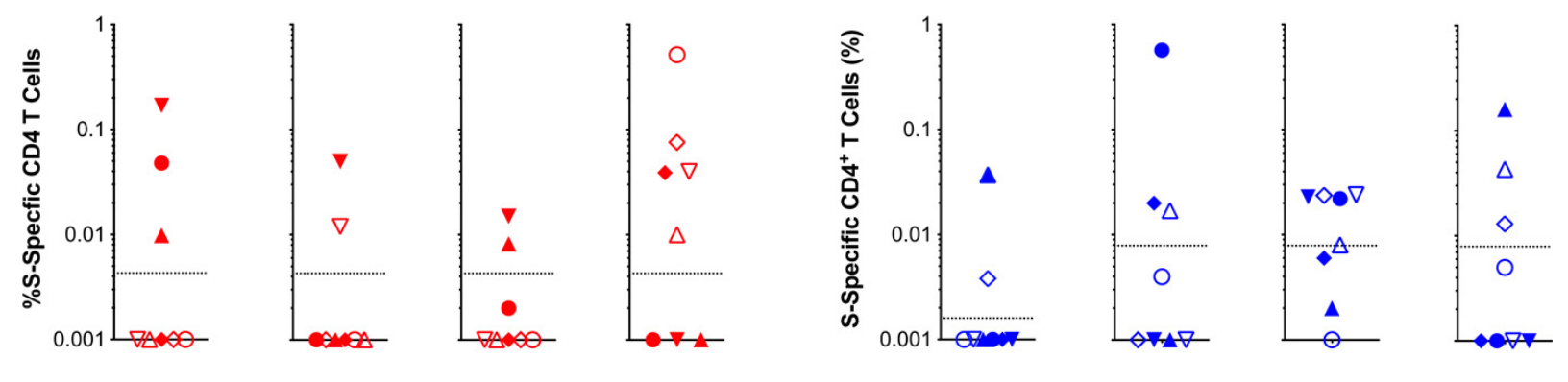

\section{Week 14}
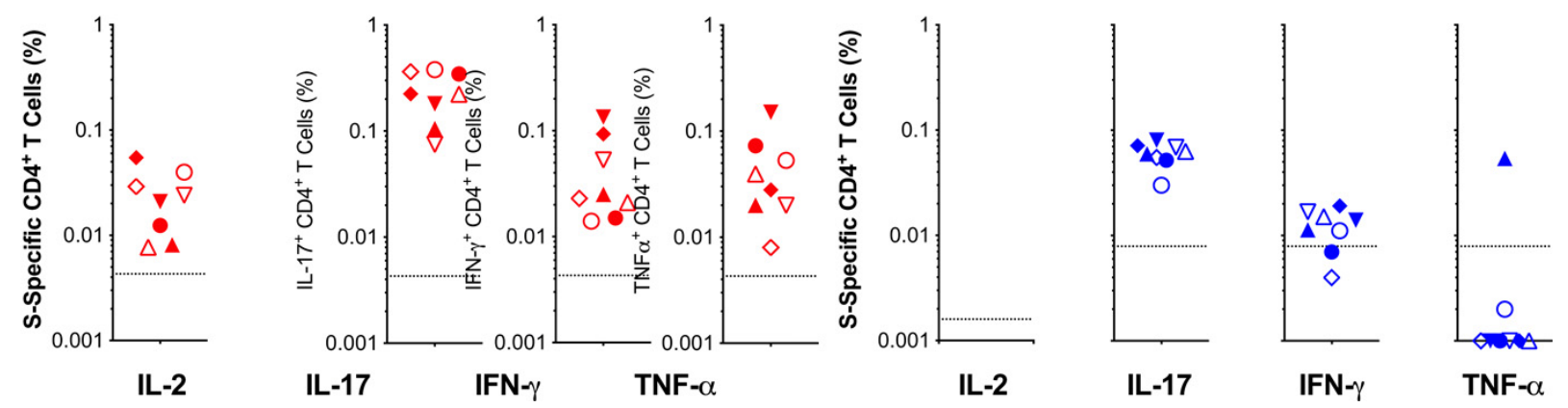

Fig. 6. Spike-specific CD4+ $\mathrm{T}$ cell responses in SARS-CoV-2 immunized infant macaques. Intracellular cytokine staining for IL-2, IL-17, IFN- $\gamma$, and TNF- $\alpha$ (indicated at the $x$-axis in Panel D) was performed on PBMC at weeks 4 (A), 6 (B), 8 (C), and 14 (D) to assess T-cell responses to a peptide pool encompassing the entire SARS-CoV-2 spike protein (see Fig. S16 for gating strategy). Responses detected in mRNA-LNP recipients are displayed in red and cytokine responses from Protein+3M-052+SE vaccinees are in blue. The dashed lines represent week 0 values plus 2 standard deviations and define the cutoff for positive cytokine responses. Different symbols represent individual animals (Table 1 ). 
Table 1. Overview of study animals.

\begin{tabular}{lcccc}
\hline Vaccine Group & Animal ID & Sex & $\begin{array}{c}\text { Age at W0 } \\
\text { (months) }\end{array}$ & Graphical Symbol \\
\hline Protein+3M-052-SE & RM 1 & male & 2.6 & blue: \\
& RM 2 & female & 2.4 & filled circle \\
& RM 3 & male & 2.3 & filled triangle \\
& RM 4 & female & 2.3 & open triangle \\
& RM 5 & female & 2.2 & open inverted triangle \\
RM 6 & male & 2.1 & filled inverted triangle \\
& RM 7 & female & 2.0 & open diamond \\
RM 8 & male & 1.6 & filled diamond \\
& & & & red: \\
mRNA-LNP & RM 9 & female & 2.5 & open circle \\
& RM 10 & male & 2.4 & filled circle \\
RM 11 & male & 2.4 & filled triangle \\
RM 12 & female & 2.3 & open triangle \\
RM 13 & male & 2.2 & filled inverted triangle \\
& RM 14 & female & 2.1 & open inverted triangle \\
RM 15 & male & 2.1 & filled diamond \\
RM 16 & female & 2.1 & open diamond \\
\hline
\end{tabular}


Table 2. mRNA-1273 Vaccine-induced immune responses in adult NHP and humans.

\begin{tabular}{|c|c|c|c|c|}
\hline \multirow{2}{*}{ Study $^{\mathrm{a}}$} & \multicolumn{4}{|c|}{ Immunogenicity } \\
\hline & $\begin{array}{c}\text { Binding Anti- } \\
\text { bodies }^{\mathrm{b}}\end{array}$ & Pseudovirus $^{\mathrm{c}}$ & Live Virus & sponses \\
\hline
\end{tabular}

\title{
Current Infant NHP Study
}

(30 pg)

4 weeks post $2^{\text {nd }}$ dose

$$
\begin{aligned}
& \text { AUC }\left(\log _{10}\right): 7.0 \\
& \text { GMT: } 55,564
\end{aligned}
$$

$\mathrm{ID}_{50}: 3,174$

$\mathrm{ID}_{50}: 12,068$

$\mathrm{T}_{\mathrm{H}} 1 ;$

IL-21 ${ }^{+} \mathrm{T}_{\mathrm{H}}$

10 weeks post $2^{\text {nd }}$ dose

\begin{abstract}
AUC $\left(\log _{10}\right): 6.2$
GMT: 19,054
\end{abstract}

$\mathrm{ID}_{50}: 1,199$

$\mathrm{ID}_{50}: 1,379$

\section{Adult NHP}

Corbett et al., N Engl J Med. 2020; 383(16):1544-1555

4 weeks post $2^{\text {nd }}$ dose
$10 \mu \mathrm{g}$
AUC: $8,421^{\mathrm{d}}$
$\mathrm{ID}_{50}: 103^{\mathrm{d}}$
$\mathrm{ID}_{50}: 501^{\mathrm{d}, \mathrm{e}}$
$\mathrm{T}_{\mathrm{H}} 1>\mathrm{T}_{\mathrm{H}} 2$;
$100 \mu \mathrm{g}$
AUC: $36,186^{\mathrm{d}}$
$\mathrm{ID}_{50}: 1,862^{\mathrm{d}}$
$\mathrm{ID}_{50}: 3,481^{\mathrm{d}, \mathrm{e}}$
IL-21 ${ }^{+} \mathrm{T}_{\mathrm{FH}}$

Corbett et al., bioRxiv;doi.org/10.1101/2021.04.20.440647

4 weeks post $2^{\text {nd }}$ dose
$30 \mu \mathrm{g}$
GMT: $64,000^{\mathrm{f}}$
$\mathrm{ID}_{50}: \sim 10^{3 \mathrm{f}}$
$\mathrm{T}_{\mathrm{H}} 1>\mathrm{T}_{\mathrm{H}} 2 ;$
IL-21 $1^{+} \mathrm{T}_{\mathrm{FH}}$

Human Adults (18-55 years)

Jackson et. al

N Engl J Med. 2020; 383(20):1920-1931.

4 weeks post $2^{\text {nd }}$ dose
$10 \mu \mathrm{g}$
GMT: $299,751^{\mathrm{d}}$
$\mathrm{ID}_{50}: 81^{\mathrm{d}}$
$100 \mu \mathrm{g}$
GMT: $782,719^{\mathrm{d}}$
$\mathrm{ID}_{50}: 232^{\mathrm{d}}$
$250 \mu \mathrm{g}$
GMT: $1,192,154^{\mathrm{d}}$
$\mathrm{ID}_{50}: 270^{\mathrm{d}}$
2 weeks post $2^{\text {nd }}$ dose

$\begin{array}{lccc}10 \mu \mathrm{g} & \text { GMT: } 379,764^{\mathrm{d}} & \text { ID }_{50}: 112^{\mathrm{d}} & \text { ID }_{80}: 340^{\mathrm{d}, \mathrm{g}} \\ 100 \mu \mathrm{g} & \text { GMT: } 811,119^{\mathrm{d}} & \text { ID }_{50}: 344^{\mathrm{d}} & \text { ID }_{80}: 654^{\mathrm{d} \cdot \mathrm{g}} \\ 250 \mu \mathrm{g} & \text { GMT: } 994,629^{\mathrm{d}} & \text { ID }_{50}: 332^{\mathrm{d}} & \text { no data }\end{array}$

Anderson et al., N Engl J Med. 2020; 383(25): 2427-2438.

4 weeks post $2^{\text {nd }}$ dose

$25 \mu \mathrm{g}$

GMT: $323,945^{\mathrm{d}}$

$100 \mu \mathrm{g}$

GMT: $1,183,066^{\mathrm{d}} \quad$ ID $_{50}: 402^{\mathrm{d}}$

$\mathrm{ID}_{50}: 878^{\mathrm{d}, \mathrm{e}}$

$\mathrm{T}_{\mathrm{H}} 1>\mathrm{T}_{\mathrm{H}} 2$

Widge et al., N Engl J Med. 2021; 384(1):80-82.

3 months post $2^{\text {nd }}$ dose
$100 \mu \mathrm{g}$
GMT: $235,228^{\mathrm{f}}$
$\mathrm{ID}_{50}: 182^{\mathrm{g}}$
$\mathrm{ID}_{50}: 775^{\mathrm{g}, \mathrm{e}}$

${ }^{\mathrm{a}}$ Study listed with reference, time of immune analysis for reported data, and vaccine dose

${ }^{\mathrm{b}}$ Plasma Binding IgG levels against spike protein are reported as area under the curve (AUC) or geometric mean titers (GMT). Note that the SARS-CoV-2 strain from which the spike antigen for the assay was derived is listed under each study.

${ }^{\mathrm{c}}$ Lentiviral-based pseudovirus neutralization (PsVNA)

${ }^{\mathrm{d}}$ Wuhan.Hu.1 spike protein

${ }^{\mathrm{e}}$ Focus reduction neutralization test (FRNT)

${ }^{\mathrm{f}}$ D614G spike protein

${ }^{\mathrm{g}}$ SARS-CoV-2 Plaque-reduction neutralization testing (PRNT) 


\section{ScienceImmunology}

\section{SARS-CoV-2 vaccines elicit durable immune responses in infant rhesus macaques}

Carolina Garrido, Alan D. Curtis II, Maria Dennis, Sachi H. Pathak, Hongmei Gao, David Montefiori, Mark Tomai, Christopher B. Fox, Pamela A. Kozlowski, Trevor Scobey, Jennifer E. Munt, Michael L. Mallory, Pooja T. Saha, Michael G. Hudgens, Lisa C

Lindesmith, Ralph S. Baric, Olubukola M. Abiona, Barney Graham, Kizzmekia S. Corbett, Darin Edwards, Andrea Carfi, Genevieve Fouda, Koen K. A. Van Rompay, Kristina De Paris and Sallie R. Permar

Sci. Immunol. 6, eabj3684.

DOI: 10.1126/sciimmunol.abj3684

ARTICLE TOOLS

SUPPLEMENTARY

MATERIALS

REFERENCES

PERMISSIONS http://immunology.sciencemag.org/content/6/60/eabj3684

http://immunology.sciencemag.org/content/suppl/2021/06/11/6.60.eabj3684.DC1

This article cites 78 articles, 23 of which you can access for free http://immunology.sciencemag.org/content/6/60/eabj3684\#BIBL

http://www.sciencemag.org/help/reprints-and-permissions

Use of this article is subject to the Terms of Service

Science Immunology (ISSN 2470-9468) is published by the American Association for the Advancement of Science, 1200 New York Avenue NW, Washington, DC 20005. The title Science Immunology is a registered trademark of AAAS.

Copyright @ 2021, American Association for the Advancement of Science 